Buildings

Elsevier Editorial System(tm) for Energy and

Manuscript Draft

Manuscript Number: ENB-D-14-01940R2

Title: Lifecycle Costing of Low Energy Housing Refurbishment: A case study of a 7 year retrofit in Chester Road, London

Article Type: Full Length Article

Keywords: sustainable refurbishment, lifecycle analysis, residential buildings, lifecycle costing, payback, Enerphit

Corresponding Author: Mrs. T. I. Neroutsou,

Corresponding Author's Institution: University College London

First Author: T. I. Neroutsou

Order of Authors: T. I. Neroutsou

Abstract: The low energy retrofit of the UK existing building stock is an urgent matter after the government's commitment to reduce carbon emissions by 80\% until 2050. This research addressed the question of whether it is preferable to refurbish in an extensive way or to choose a retrofit strategy with lower capital cost, embodied energy and Co2, tackling issues of cost-effectiveness, embodied and operational energy throughout the lifecycle of an existing Victorian house in London. The indicator Cost per Ton carbon saved (CTS) was used, which resulted in higher values for the EnerpHit retrofit model, rendering it a less viable alternative. It was also concluded that retrofitting, in general and especially the application of EnerPHit, is an appealing option only with rising gas prices, low discount rates and long lifespans. Those results were even more amplified when climate change was taken into account, a conclusion very important for the application of future legislation and the possible transfer of this study to other climates. It was deduced that a house's remaining lifetime is a very significant factor to be taken into account, as investments of higher capital cost give higher benefit in long term. 
5

\section{Lifecycle Costing of Low Energy Housing Refurbishment: A case study of a 7 year retrofit in Chester Road, London T.I.Neroutsou ${ }^{1}$ University College London, London, UK Email: dora.neroutsou@gmail.com, Tel: +306937109717}

\section{ABSTRACT}

The low energy retrofit of the UK existing building stock is an urgent matter after the government's commitment to reduce carbon emissions by $80 \%$ until 2050 . This research addressed the question of whether it is preferable to refurbish in an extensive way or to choose a retrofit strategy with lower capital cost, embodied energy and $\mathrm{CO}_{2}$, tackling issues of cost-effectiveness, embodied and operational energy throughout the lifecycle of an existing Victorian house in London. The indicator Cost per Ton carbon Saved (CTS) was used, which resulted in higher values for the EnerPHit retrofit model, rendering it a less viable alternative. It was also concluded that retrofitting, in general and especially the application of EnerPHit, is an appealing option only with rising gas prices, low discount rates and long lifespans. Those results were even more amplified when climate change was taken into account, a conclusion very important for the application of future legislation and the possible transfer of this study to other climates. It was deduced that a house's remaining lifetime is a very significant factor to be taken into account, as investments of higher capital cost give higher benefit in long term.

\section{KEYWORDS: sustainable refurbishment, lifecycle analysis, residential buildings}

\section{HIGHLIGHTS}

- Two retrofitting strategies were compared based on cost-effectiveness, embodied and operational energy and $\mathrm{CO} 2$.

- The Cost per Ton carbon Saved was higher for the most extensive one.

- The cost-effectiveness of retrofitting depends on gas prices, discount rates, the building's lifespan and the climatic factor.

\section{ABBREVIATIONS}

CO2: Carbon Dioxide

CTS: Cost per Ton of carbon Saved

ECO2: Embodied Carbon

EE: Embodied Energy

EU: European Union

IC: Initial Cost

LC: Lifetime Cost

LCC: Life Cycle Costing

LCS: Lifetime Carbon Saved

LE: Low Energy

NPV: Net Present Value

OC: Operational Cost

OCO2: Operational Carbon
OE: Operational Energy

$\mathrm{PH}$ : Passive House

PHPP: Passive House Planning Package

ppm: parts per million

PV: Photovoltaic

$r$ : discount rate

SAP: Standard Assessment Procedure

SCC: Social Cost of Carbon

TAS: Thermal Analysis Simulation

TRY: Test Reference Year

UK: United Kingdom

WLCC: Whole Life Cycle Costing

XPS: Extruded Polystyrene

\footnotetext{
${ }^{1}$ Present Address: 140 Lomvardou St. Athens, Greece
} 


\section{INTRODUCTION}

Dwellings account for $60 \%$ of European Union building energy use, $40-60 \%$ of which is used for heating and with $80 \%$ of the existing building stock proven to exist in 2050 (Thorpe, 2010). With the Climate Change Act (HMSO, 2008) low carbon retrofitting of this stock becomes a necessity for the United Kingdom, as it sets targets of $80 \%$ reduction in net carbon account emissions by 2050 and $34 \%$ by 2020 with a baseline of 1990 . This policy is mainly driven by two key driving forces: climate change and energy security.

The majority of energy consumed in the domestic sector is for space heating, producing in $200925 \%$ of the total $\mathrm{CO} 2$ emissions (HMSO, 2011). Water heating, lighting and appliances accounted for a further $18 \%$ and $19 \%$ respectively (DECC, 2012).

As resulting from the above, in the context of climate change, fossil fuel insecurity and the attribution of the second biggest percentage of energy consumption to domestic buildings, it is essential to prioritize the minimization of energy in the domestic stock in the way towards an $80 \%$ reduction in $\mathrm{CO}_{2}$ emissions by 2050. With heating making up the biggest part of the consumption, increasing the insulation levels and the heating systems' efficiency in the existing building stock is expected to result in a big improvement.

The aim of this work is to address the topic of sustainable refurbishment of the existing building stock, by tackling the issues of cost - effectiveness, embodied and operational energy throughout the lifecycle of a residential building. This is researched by comparing a case study refurbishment complying with Part L1 B and a hypothetical refurbishment complying with Passive House ${ }^{2}(\mathrm{PH})$ standards for refurbishments (EnerPHit), under the prism of Cost per Ton carbon Saved. The effect of individual measures was assessed under the same perspective. Thus, this study addresses the debate of whether it is preferable to refurbish in an extensive way (insulating as much as possible), in order to achieve the minimum operational energy or to choose a retrofit strategy with lower capital cost, embodied energy and $\mathrm{CO} 2$, which will, hypothetically, be paid back earlier.

\section{LIFE CYCLE COSTING AND LOW ENERGY RETROFIT}

In order to assess the optimum retrofit strategy for existing buildings, Life Cycle Costing (LCC) was used in numerous studies, underlying the importance of considering the building as an energy system throughout its lifetime. LCC is the total cost of a building or its parts throughout its life, including the costs of Acquisition (including pre-construction and construction), Operation, Maintenance, Replacement (or refurbishment) and Disposal (sale or demolition) (ISO, 2003). It is a technique which enables comparative cost assessments to be made over a specified period of time, taking into account all relevant economic factors both in terms of initial capital and future operational costs. In particular, it is an economic assessment considering all projected relevant cost flows over a period of analysis expressed in monetary value (ISO, 2003).

Retrofitting aims to the minimization of operational energy, however, focusing solely on the operation phase may bring less overall benefits due to potential trade-offs in other life cycle phases. According to a study (Feist, 1997) comparing the cumulative primary energy input over a lifetime of 80 years of six construction standards, the total production energy input for the $\mathrm{PH}$ was $1391 \mathrm{kWh} / \mathrm{m}^{2}$, with thermal insulation measures accounting for $14 \%\left(194 \mathrm{kWh} / \mathrm{m}^{2}\right)$. The study claims that thermal insulation and ventilation saved $123 \mathrm{kWh} /\left(\mathrm{m}^{2} \mathrm{a}\right)$ on primary energy, having, thus, less than two years payback time.

\footnotetext{
2 The building must be designed to have an annual heating and cooling demand of not more than $15 \mathrm{kWh} / \mathrm{m} 2 \mathrm{a}$ in heating or cooling energy OR be designed with a peak heat load of $10 \mathrm{~W} / \mathrm{m} 2$. The total primary energy consumption must not be more than $120 \mathrm{kWh} / \mathrm{m} 2 \mathrm{a}$. The building must not leak more air than 0.6 times the house volume per hour (n50 $\leq 0.6 /$ hour) at $50 \mathrm{~Pa}$ as tested by a blower door.
} 
In the Life-Cycle primary energy balance for the 'reference ${ }^{3}$, low energy ${ }^{4}$ (LE), PH and self-sufficient house, it was obvious that the latter was always above the $\mathrm{PH}$, while the starting points for the five first types were very close, contradicting the argument that $\mathrm{PH}$ has a significantly bigger initial energy input compared to standard buildings.

The 'Arbeitskreis Kostengünstige Passivhäuser, 1997' (Research Group on Cost Efficient Passive Houses) (Passipedia) concluded that the condition of the building prior refurbishment strongly determines whether an energy saving measure can be considered economical or not. It was also claimed that the implied extra investment of a PH retrofit leads to an overall gain during the lifetime of the components, with careful planning and implementation processes. Most importantly, it was inferred that the highest levels of thermal protection measures available were also the optimum ones, in terms of cost effectiveness, based on the 'do it as good as possible' principle.

A study comparing the retrofit of a 1950 Belgian dwelling to common practice, LE and PH standard (not EnerPHit standard) concluded that, although the $\mathrm{PH}$ retrofit saves on $87 \%$ on heating demand, in contrast to $63 \%$ of the LE one, its initial cost's payback period is highly dependent on fuel price increase. With $2 \%$ increase the PH is not paid back not even in 40 years, making LE more cost effective, while with the improbable $10 \%$ fuel price increase, the payback time is 18.4 years (Versele 2008).

On the other hand, Hermelink (2009) compared an existing PH development to a fictitious LE alternative based on environmental life cycle assessment, assuming constant gas prices. He found that construction and maintenance/repair have a relatively high environmental impact, exceeding the impact of space heating. Moreover, it was concluded that the slightly higher environmental impact of $\mathrm{PH}$ building stemming from construction and maintenance/repair is clearly over-compensated by its significantly lower operational energy consumption. While assessing the $\mathrm{CO} 2$ emissions of the two LE building types, it was found that the LE would fail the 2050 target and the PH hardly reaches it, mainly due to the carbon intensity of electricity generation. From the cost point of view, as well, PH appears to be the most attractive solution, especially with increased gas and electricity prices.

Dodoo et al. (2010) and Gustafsson and Karlsson (1988) highlighted the importance of the type of energy supply system which is substituted by the retrofit, concluding that the un insulated building with district heating has a lower life cycle primary energy use than if the same building was retrofitted to the PH standard and heated electrically. Similarly to Feist (1997), a 4 year payback period of the primary energy for building construction through the operational energy savings was assessed.

The payback period of an energy retrofit is highly dependent on fuel prices and weather data and, as resulted from the Whole Life Cycle Costing study of Mohammadpourkarbasi (2013) of a refurbished Victorian house under three gas prices and three weather scenarios, such an investment is only economically attractive with the rising gas prices scenario, although the additional costs of maintenance and replacement of the base case house were not taken into account, which is expected to alter the results. Interestingly, the cumulative cash flow of the refurbished near to PH standard building shows that the payback time from heating saved will be 27 years with upward prices and may never realistically pay back if prices fall or remain constant.

It is important to stress, however, the importance of the boundary condition of each study in the validity of the results. Fuel prices, construction costs, risk rates and climatic conditions affect significantly the outcome of the cost assessment.

\section{METHODOLOGY}

\footnotetext{
${ }^{3}$ A mid-terrace house (156 m2) complying to the 1984 German Thermal Insulation Ordinance (WschVO 84) was taken as reference house.

${ }_{5}^{4}$ Annual heat requirement below $70 \mathrm{kWh} /(\mathrm{m} 2 \mathrm{a})$.

${ }^{5}$ Needs no end-use energy deliveries - apart from the incident energy flows from natural sources (solar radiation, wind).
} 
An existing house was selected as the case study, which is located at 73 Chester Road, Dartmouth Park, London. The case study house is a Victorian semi - detached end terrace house built before 1919. It is formed by two volumes, a three - storey one in the front, facing North West, and a two - storey extension in the rear, with a total usable floor area of approximately $167 \mathrm{~m}^{2}$ (Figure 1,2). Between June and December 2006 and under the direction of the house's owner, the house underwent major refurbishment works that are summarised in Table 1.

Figure 1 Front Elevation

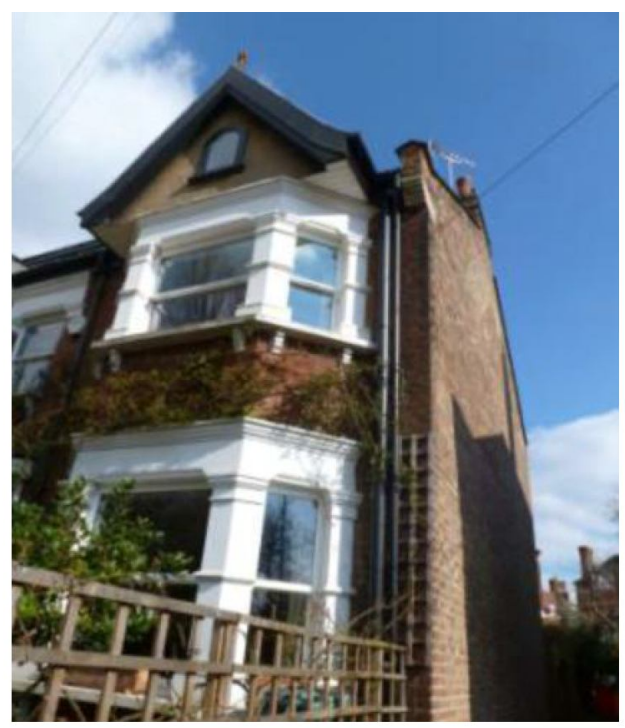

Figure 2 Ground Floor Plan (not in scale)

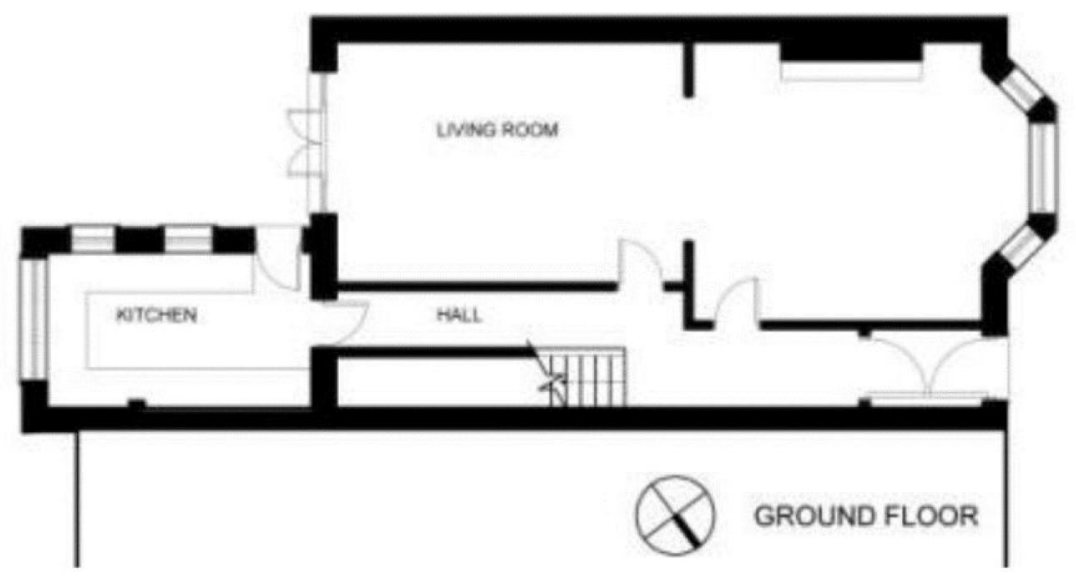

Table 1 Refurbishment of building envelope

\begin{tabular}{|l|l|}
\hline Element & \multicolumn{1}{|c|}{ Refurbishment description } \\
\hline \multirow{4}{*}{ Walls } & $\begin{array}{l}\text { Double brickwork } 220 \mathrm{~mm} \\
\text { Internal insulation with } 100 \mathrm{~mm} \text { Diffutherm woodfibre boards (U= } \\
\left.0.043 \mathrm{~W} / \mathrm{m}^{2} \mathrm{~K}\right)\end{array}$ \\
\cline { 2 - 2 } & $\begin{array}{l}50 \mathrm{~mm} \text { insulation installed in the kitchen, the bathroom and } \\
\text { around the fireplace }\end{array}$ \\
\hline Party wall & Kitchen: partly insulated $(130 \mathrm{~cm}$ from the junction with the \\
\hline
\end{tabular}




\begin{tabular}{|c|c|}
\hline & $\begin{array}{l}\text { external wall) } \\
\text { Bathroom: insulated for the whole length Hall: above the height } \\
\text { of } 7 \mathrm{~m}\end{array}$ \\
\hline Side wall & Re-pointed with a cement mortar with moisture resistance \\
\hline Roof & $\begin{array}{l}100 \mathrm{~mm} \text { rockwool installed between the rafters, two layers of } \\
\text { Diffutherm }(40 \mathrm{~mm}) \text { and } 22 \mathrm{~mm} \text { of Isolair }\left(\mathrm{U}=0.047 \mathrm{~W} / \mathrm{m}^{2} \mathrm{~K}\right) \text { above }\end{array}$ \\
\hline \multirow{4}{*}{ Floors } & $\begin{array}{l}\text { Living room: Suspended floor retained, floor boards replaced and } \\
\text { the old ones used in the attic. Intermediate space between the } \\
\text { joists filled with rockwool ( } 150 \mathrm{~mm} \text { ) and } 20 \mathrm{~mm} \text { of Diffutherm } \\
\text { added below them. Junctions with walls foamed }\end{array}$ \\
\hline & Hall: tiled Victorian floor not altered \\
\hline & Kitchen: solid floor insulated with $50 \mathrm{~mm}$ XPS \\
\hline & $\begin{array}{l}\text { Attic floor: insulated mainly for noise proof issues with } 100 \mathrm{~mm} \\
\text { rockwool between the joists, Regupol acoustic isolating strips on } \\
\text { joists and chipboard on top }\end{array}$ \\
\hline \multirow{7}{*}{ Windows and doors } & $\begin{array}{l}\text { Original sash windows at the front: now argon-filled double } \\
\text { glazing manufactured by Vogrum }\end{array}$ \\
\hline & $\begin{array}{l}\text { Rear living room French door: triple glazed Ecocontract }(\mathrm{U}=0.9 \\
\left.\mathrm{W} / \mathrm{m}^{2} \mathrm{~K}\right) \text {. }\end{array}$ \\
\hline & Kitchen, bathroom and attic: Rationel double $\left(\mathrm{U}=2.1 \mathrm{~W} / \mathrm{m}^{2} \mathrm{~K}\right)$ \\
\hline & First floor windows: double glazed \\
\hline & Skylights: Velux Conservation ( $\left.\mathrm{U}=1.7 \mathrm{~W} / \mathrm{m}^{2} \mathrm{~K}\right)$ \\
\hline & Windows and doors: draught - sealed \\
\hline & $\begin{array}{l}\text { Second door added to the entrance space, creating a draught } \\
\text { lobby }\end{array}$ \\
\hline
\end{tabular}

\subsection{Whole Life Cycle Costing}

Cost is a determining factor both for individual and governmental initiatives and the importance of finding the most economical choice among alternative refurbishment levels and measures in long term is vital. In this study a LCC technique has been used for comparative cost assessments, initially over a 30 year lifespan, taking into account the present value of initial capital costs, future operational costs and savings from the two different retrofit approaches. For the purpose of this paper the effects on heating consumption from improving the thermal envelope have been evaluated and specifically the LCC of wall, floor and roof insulation, replacing windows and doors have been assessed.

\subsection{Embodied Energy Inputs}

140 The Inventory of Carbon and Energy (Hammond and Jones, 2008) was used for the calculation of the $\mathrm{EE}$ and $\mathrm{ECO} 2$ of the materials used for the refurbishment. For the calculation of the window's frames', the data were obtained from the Ökobilanzdaten im Baubereich database of the Swiss Coordination of Construction and Property Institutions (KBOB). Since those databases include only data from resource extraction to factory gate (cradle to gate) and due to the fickle nature of transport's and processes' EE, it was considered that their calculation based on distances and number of vehicles used from factory to site would include many uncertainties and those were placed out of the system's boundaries. It is acknowledged, however, that this would underestimate the energy and carbon payback, although it would not induce significant differences between the two cases in comparison.

\subsection{Operational Energy, $\mathrm{CO}_{2}$ and Cost Inputs}

Operating cost is defined as the sum of energy consumption, maintenance and repair costs (Fuller 2010). The estimation of these costs is a significant factor, as the greatest part of the building's impact occurs after construction (University of Reading, 1985) and accounts for $78 \%$ - $96 \%$ of the total 
consumed energy (Gignac and Jensen, 2007). Required inputs for calculating operating costs are: energy consumption, energy cost savings, gas prices (the refurbished house is heated by gas); predicted gas price trends in the future and assumed discount rate.

Energy consumption for heating was calculated using a multi - zone thermal model produced with EDSL TAS software, having three comparison cases: pre-refurbishment, current refurbished house and EnerPHit refurbished (Table 2). The infiltration rate for the pre - refurbished state (0.53 ach @ STP) was assumed based on Johnston et al. (2011), the current state based on the blower door test results of 5.6 ach/h @ n50 (0.3 ach @ STP) and reduced by one third ( 0.2 ach @ STP) for the EnerPHit, as the target of 1 (0.05 ach @ STP) was considered unachievable. For the simulations the London Heathrow CIBSE TRY weather file was used, causing probably some deflection from the actual weather conditions (centre of London).

Table 2 Summary of the three iterations' $U$ values $\left(W / m^{2} K\right)$

\begin{tabular}{|c|c|c|c|}
\hline & Pre refurbishment & Current state & EnerPHit \\
\hline External Wall - Front Facade & 1.24 & 0.32 & 0.13 \\
\hline External Walls & 1.24 & $0.5 /$ \\
\hline Party Wall & 0.73 & 0.32 & 0.21 \\
\hline Attic Wall & 2.17 & 0.24 & 0.14 \\
\hline Roof & 3.11 & 0.20 & 0.13 \\
\hline Attic Floor & 2.27 & 0.35 & 0.35 \\
\hline Intermediate Floor & 2.06 & 2.06 & 2.06 \\
\hline Kitchen Floor & 0.96 & 0.32 & 0.15 \\
\hline Hall Floor & 0.96 & 0.96 & 0.15 \\
\hline Living room Floor & 0.78 & 0.18 & 0.134 \\
\hline Windows & 4.80 & $\begin{array}{l}0.8 / \\
1.7 /\end{array}$ & 2.1 \\
\hline
\end{tabular}

The actual house consumption metering files were used for the calculation of hot water heating and electricity consumption. Both calculated and actual energy consumptions were divided by efficiency factors and multiplied by carbon factors. Cost factors were calculated according to Quarterly Energy Prices Indices 2013 (National Statistics, 2013),(Table 3).

Table 3 Efficiency and CO2 factors (Department of Environment Food and Rural Affairs, 2007a, National Statistics, 2013)

\begin{tabular}{|c|c|c|c|}
\hline Fuel Type & Carbon Factor (kg/KWh) & Efficiency & Cost Factor (f/KWh) \\
\hline Gas & 0.19 & 0.90 & 0.04 \\
\hline Electricity & 0.52 & 1.00 & 0.14 \\
\hline Wood & 0.08 & 0.80 & 0.04 \\
\hline
\end{tabular}

\subsection{Indicators}

The main indicator used for the comparison between the two cases is CTS, which is derived from 175 Equation 1.

CTS $(f / \mathrm{tCO} 2)=\frac{\text { Lifetime Cost }}{\text { Carbon Saved }}(1)$ where 
Carbon Saved $(\mathrm{tCO} 2)=\frac{\text { (OCO2 pre refurbishment }-0 \mathrm{CO} 2 \text { after refurbishment) } \mathrm{x} \text { Lifespan-ECO2 }}{1000}$

Lifetime Cost $(£)=(O C$ pre refurbishment-OC after refurbishment) $x$ Lifespan $-I C$

Table 4 Indicators and Units

\begin{tabular}{|l|l|l|}
\hline Indicator Abbreviation & Indicator & Unit \\
\hline $\mathrm{CTS}$ & Cost per Ton carbon Saved & $\mathrm{f} / \mathrm{tCO} 2$ \\
\hline $\mathrm{OCO} 2$ & Operational CO2 & $\mathrm{Kg} / \mathrm{m} 2$ annum \\
\hline $\mathrm{ECO} 2$ & Embodied CO2 & $\mathrm{Kg} / \mathrm{m} 2$ \\
\hline $\mathrm{OC}$ & Operational Cost & $\mathrm{f} / \mathrm{m} 2$ annum \\
\hline $\mathrm{IC}$ & Initial Cost & $\mathrm{f} / \mathrm{m} 2$ \\
\hline $\mathrm{OE}$ & Operational Energy & $\mathrm{MJ} / \mathrm{m} 2$ annum \\
\hline $\mathrm{EE}$ & Embodied Energy & $\mathrm{MJ} / \mathrm{m} 2$ \\
\hline
\end{tabular}

\section{LIFE CYCLE ANALYSIS}

The operational energy use was compared between the pre-refurbishment condition, the current and the retrofitted according to EnerPHit standard (Figure 3).

Figure 3 Passive measures (thermal envelope only)

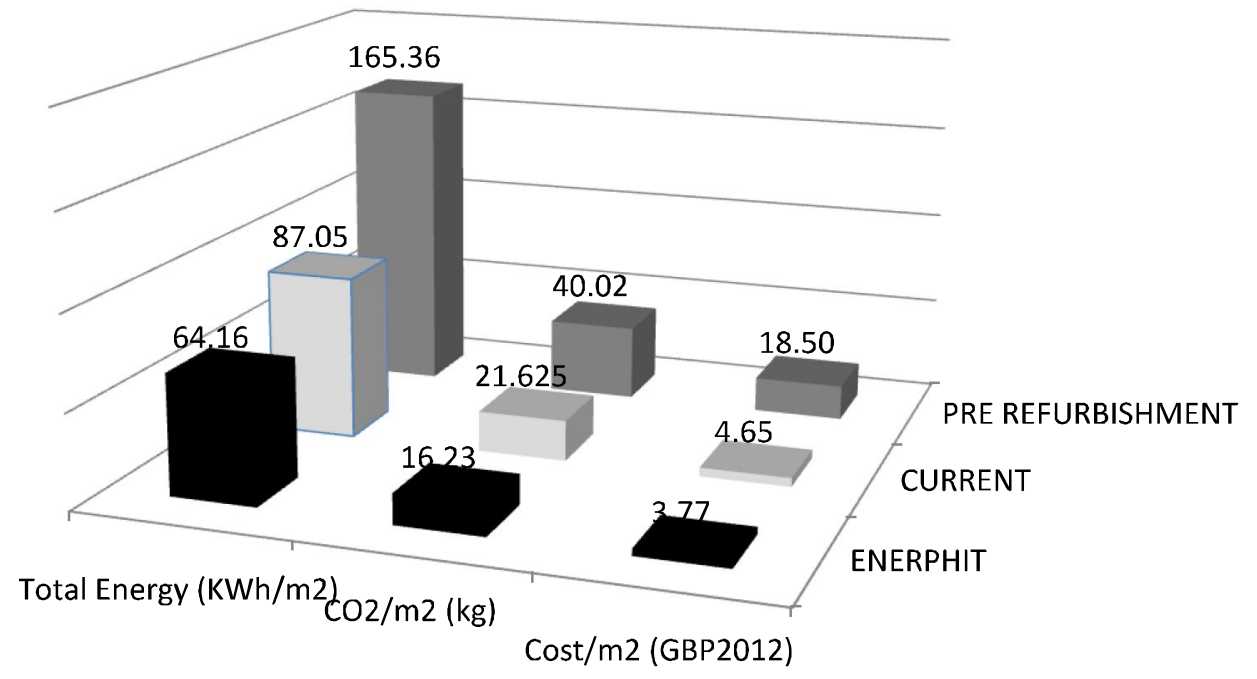

The current house performs significantly better than prior refurbishment, with a $47 \%$ reduction in total energy consumption and $70 \%$ in heating load, while the EnerPHit house would perform even better, with $61 \%$ and $85 \%$ reduction respectively. By comparison, the average heating consumption for the existing UK building stock is $180 \mathrm{kWh} / \mathrm{m}^{2} \mathrm{a}, 100 \mathrm{kWh} / \mathrm{m}^{2}$ a when renovated and $50-60 \mathrm{kWh} / \mathrm{m}^{2} \mathrm{a}$ for new build (Dowson, 2012), which indicates that the current house performs significantly well. The EnerPHit house performs even better, as expected, with a heating demand below $25 \mathrm{kWh} / \mathrm{m}^{2}$ a(Figure 4). 
Figure 4 Energy Use Breakdown (KWh/m2a)

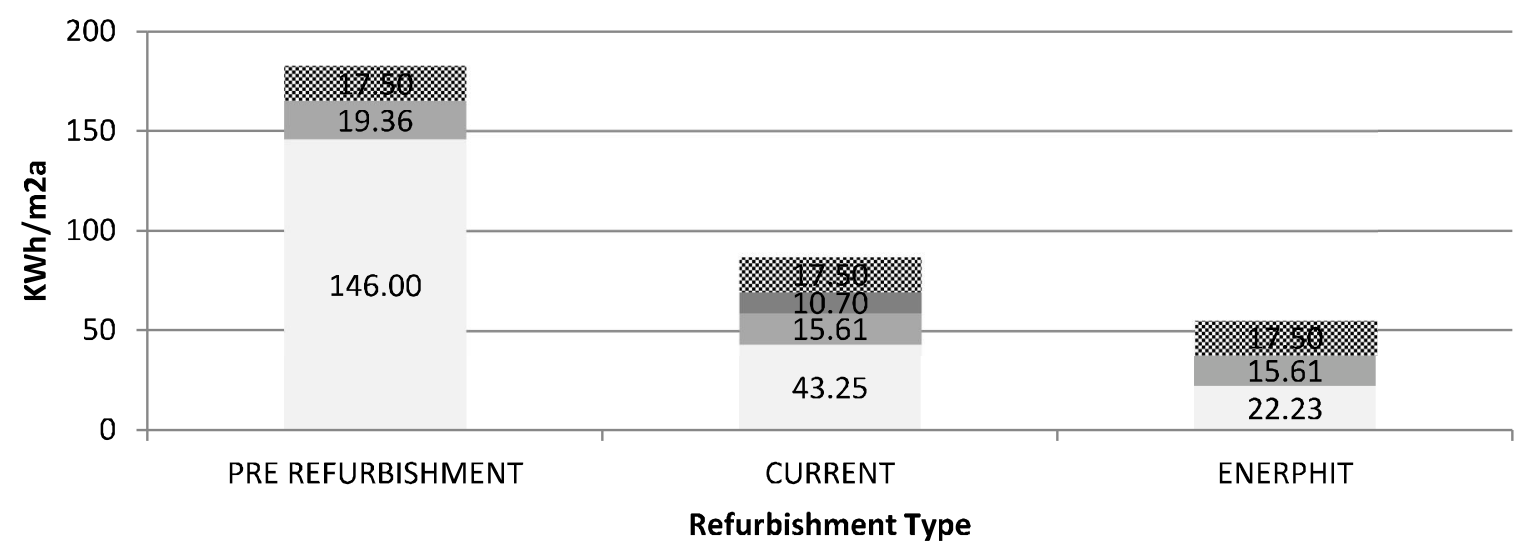

$$
\begin{aligned}
& \text { Heating Load }(\mathrm{kWh} / \mathrm{m} 2) \\
& \text { Wood stove Load }(\mathrm{KWh} / \mathrm{m} 2)
\end{aligned}
$$$$
\text { - Electrical Load (kWh/m2) }
$$$$
\text { : Water heating Load }(\mathrm{kWh} / \mathrm{m} 2)
$$

In the energy use breakdown (Figure 4) it becomes apparent that the primary source of energy consumption is space heating in all cases. The initial un-insulated house had a very high heat space demand, due to high heat losses through the opaque and glazed areas and infiltration as well, which made the improvement of the thermal envelope imperative.

\subsection{The impact of different thermal measures}

The effect of various thermal improvement measures are summarised in Figure 5 and Table. As expected, due to the reduced U-values, the EnerPHit measures reduce heating loads more than the applied refurbishment, with external wall and roof insulation and window replacement having the greatest impact in both cases. A further analysis of individual measures is presented in Section 4.7.

\section{Figure 5 Heating Loads and retrofit measures}

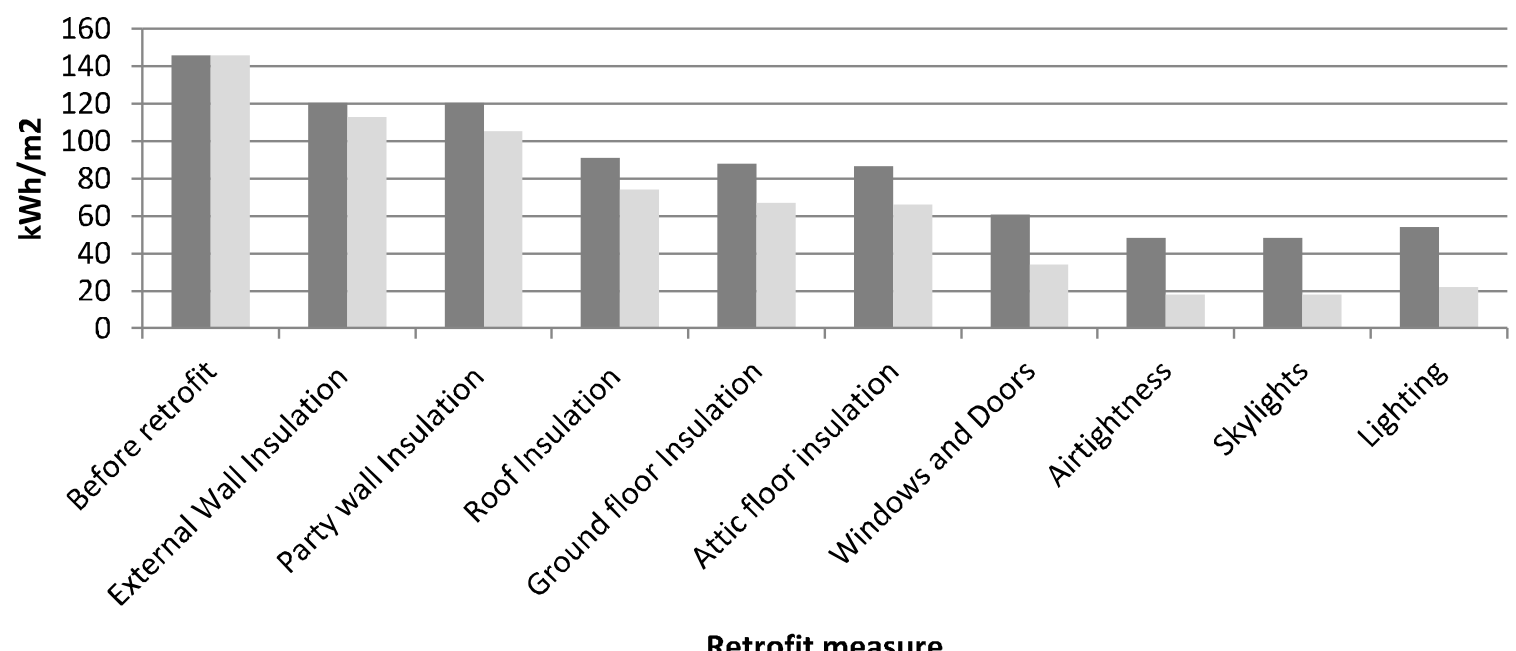

\section{Retrofit measure}

Current refurbishment Enerphit refurbishment 
Table 5 Retrofit measures' effect on heating loads

\begin{tabular}{|c|c|c|c|c|c|c|c|c|c|c|}
\hline \multicolumn{11}{|c|}{ Current refurbishment } \\
\hline & 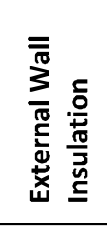 & 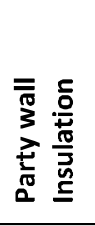 & 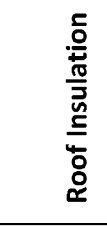 & 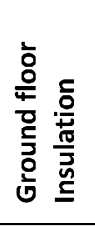 & 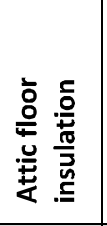 & 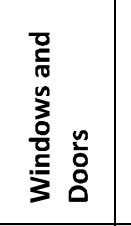 & 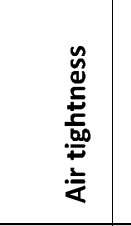 & 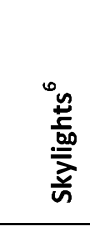 & & 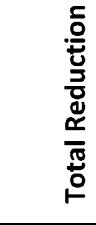 \\
\hline Before $(\mathrm{KWh} / \mathrm{m} 2)$ & 146.0 & 120.3 & 120.2 & 91.2 & 88.0 & 86.8 & 61.0 & 48.3 & 48.4 & \\
\hline After(KWh/m2) & 120.3 & 120.2 & 91.2 & 88.0 & 86.8 & 61.0 & 48.3 & 48.4 & 53.9 & \\
\hline Difference $(\mathrm{KWh} / \mathrm{m} 2)$ & -25.7 & -0.1 & -29.0 & -3.2 & -1.2 & -25.8 & -12.7 & 0.1 & 5.6 & -92.1 \\
\hline Difference (\%) & $-17.6 \%$ & $-0.1 \%$ & $-24.1 \%$ & $-3.5 \%$ & $-1.4 \%$ & $-29.7 \%$ & $-20.8 \%$ & $0.2 \%$ & $11.5 \%$ & $-63.0 \%$ \\
\hline \multicolumn{11}{|c|}{ EnerPHit refurbishment } \\
\hline Before (KWh/m2) & 146.0 & 112.7 & 105.4 & 74.1 & 67.0 & 66.1 & 34.2 & 18.2 & 18.1 & \\
\hline After(KWh/m2) & 112.7 & 105.4 & 74.1 & 67.0 & 66.1 & 34.2 & 18.2 & 18.1 & 22.2 & \\
\hline Difference $(\mathrm{KWh} / \mathrm{m} 2)$ & -33.3 & -7.3 & -31.3 & -7.1 & -1.0 & -31.9 & -16.0 & -0.1 & 4.2 & -123.8 \\
\hline Difference (\%) & $-22.8 \%$ & $-6.5 \%$ & $-29.7 \%$ & $-9.6 \%$ & $-1.4 \%$ & $-48.3 \%$ & $-46.8 \%$ & $-0.7 \%$ & $23.1 \%$ & $-84.8 \%$ \\
\hline
\end{tabular}

\subsection{Embodied Costs}

As far as costs are concerned, all calculations were based on 2013 prices, the PH retrofit cost accounts for $130 \%$ more than the current one. Figure 6 shows that in both cases the most expensive intervention is the replacement of windows. Interestingly, the current roof refurbishment cost is 2.7 times higher than the EnerPHit, which is attributed to the big price difference between Diffutherm $80 \mathrm{~mm}(£ 31.3 / \mathrm{m} 2)$ and Mineral Wool $80 \mathrm{~mm}(£ 3 / \mathrm{m2})$. The same applies in the case of external walls, where the same thickness of Woodfibre board costs more than 2.5 times higher than XPS. Thus, the extra cost for increased rafter depth and scaffolding imposed by external wall insulation is almost equalised to the current retrofit's costs. As expected, the $100 \%$ triple glazed windows of the EnerPHit house increase the budget by $156 \%$ compared to the current case. Finally, with regards to air tightness, for the current refurbishment there is no extra cost recorded, whereas for the decrease from 0.3 to 0.2 ach in the EnerPHit case an extra cost of $£ 1200$ was assumed (Johnston et al., 2011).

\section{Figure 6 Total Costs}

EnerPHit Refurbishment

Current Refurbishment

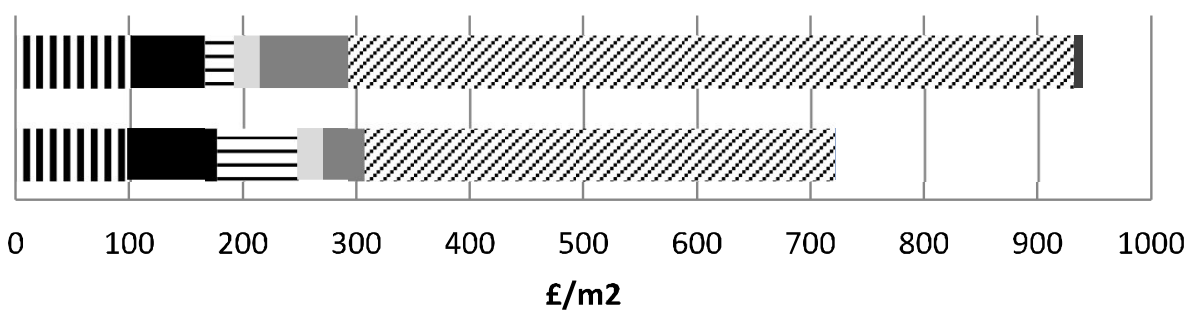

II External Walls $\square$ Party Wall =Roof Attic floor $\square$ Ground floor $\angle$ Windows and doors $\square$ Airtightness

\subsection{Embodied Energy (EE)}

\footnotetext{
${ }^{6}$ The installation of skylights is proven not to affect he thermal performance, thus it is omitted from further analysis.

${ }^{7}$ The replacement of incandescent light bulbs with fluorescent was included even if it is not a thermal envelope measure, as it influences internal gains and thus heating loads.
} 
From Figure 7 it becomes apparent that the EnerPHit refurbishment EE one is extremely higher, with walls showing the greatest difference. This is mainly attributed to the use of XPS (as imposed by the Passive House Certified Components) with $88.6 \mathrm{MJ} / \mathrm{kg} \mathrm{EE}$, instead of woodfibre board insulation with 20 $\mathrm{MJ} / \mathrm{kg}$ and the increased thickness needed to achieve the lower $U$ values for the thermal elements. In addition, the triple glazed units and the insulated wooden frames and wooden door with polyurethane foam add $13 \%$ more to the EE.

Figure 7 Embodied Energy

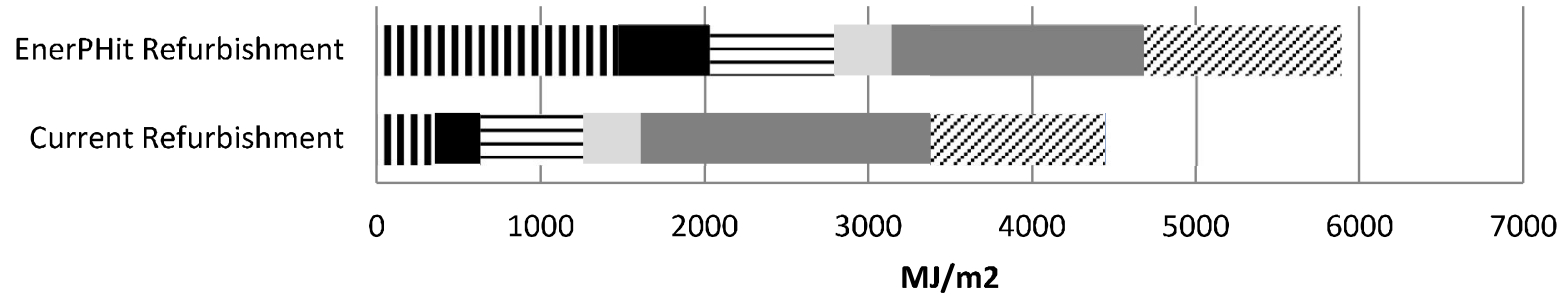

IIExternal Walls Party Wall - Roof Attic floor Ground floor $\forall$ Windows and doors

\subsection{Embodied $\mathrm{CO}_{2}$}

Embodied carbon (Figure 8) shows a huge difference between the current refurbishment and EnerPHit in the range of $357 \%$. This is also due to the use of different insulation materials and thicknesses and concrete products for the floor insulation. As described above, $1 \mathrm{~m}^{2}$ of insulation with sufficient thickness to provide $U=0.15 \mathrm{~W} / \mathrm{m} 2 \mathrm{~K}(\mathrm{R}=6.7 \mathrm{~m} 2 \mathrm{~K} / \mathrm{W})$ results to Table 6 . The difference between the XPS and the woodfibre this time is great (6 times more), justifying absolutely the divergence between the two cases.

Figure 8 Embodied $\mathrm{CO} 2$

\begin{abstract}
EnerPHit Refurbishment
Current Refurbishment
\end{abstract}

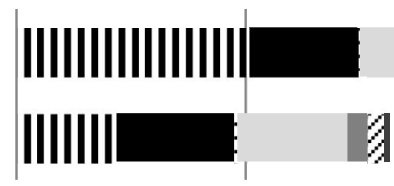

0

50

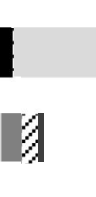

100

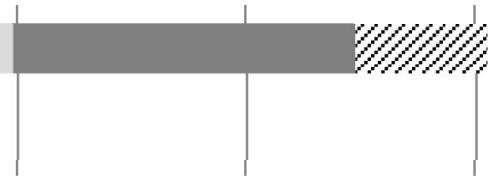

150

200

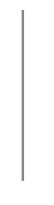

250

$\mathrm{kg} / \mathrm{m} 2$

IIExternal Walls Party Wall - Roof Attic floor Ground floor $\succsim$ Windows and doors

Table 6 Comparison of insulation ECO2

\begin{tabular}{|c|c|c|c|c|c|c|c|}
\hline Material & $\begin{array}{l}k_{(W / m K)} \text { value } \\
(\mathrm{W})\end{array}$ & $\begin{array}{l}\text { Embodied Carbon } \\
(\mathrm{Kg} \mathrm{CO} 2 / \mathrm{kg})\end{array}$ & $\mathrm{R}(\mathrm{m} 2 \mathrm{~K} / \mathrm{W})$ & $\mathrm{d}(\mathrm{m})$ & $\begin{array}{l}\text { Density } \\
(\mathrm{kg} / \mathrm{m} 3)\end{array}$ & $\mathrm{kg}$ & $\begin{array}{l}\text { Embodied Carbon } \\
\text { (Kg CO2) }\end{array}$ \\
\hline $\begin{array}{l}\text { Mineral } \\
\text { Wool }\end{array}$ & 0.044 & 1.2 & 6.7 & 0.3 & 150.0 & 330.2 & 52.83 \\
\hline Woodfibre & 0.08 & 0.12 & 6.7 & 0.5 & 180.0 & 96.0 & 11.53 \\
\hline XPS & 0.028 & 2.5 & 6.7 & 0.2 & 140.0 & 26.1 & 65.37 \\
\hline
\end{tabular}




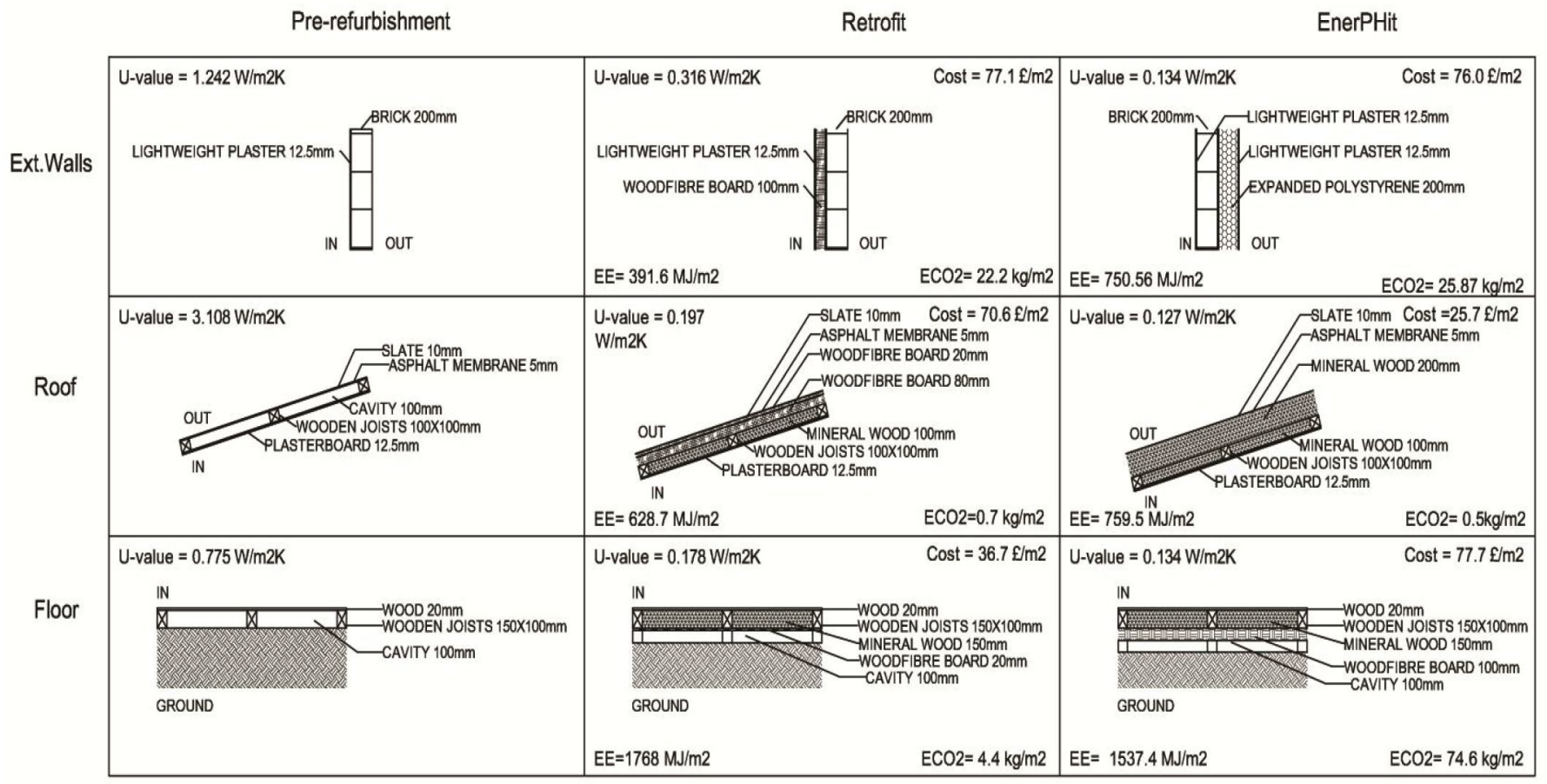

Figure 9 represents the three iterations' (pre-refurbishment, retrofit and EnerPHit) main characteristics (U-Value, Cost per m2, Embodied Energy per m2, Embodied CO2 per m2) of three main constructions (external walls, roof, and ground floor). This table summarizes and justifies the results of sections $4.2-4.4$, due to certain material properties and thicknesses and also gives a visual representation of the constructions under analysis.

For instance, it becomes apparent that in the case of the roof construction, the installation of woodfibre board (retrofit) instead of mineral wool (EnerPHit) increases the cost, while resulting in a higher thermal conductivity. Likewise, as far as external walls are concerned, the XPS (EnerPHit) instead of woodfibre board (retrofit) gives an approximate same cost with three times less U-Value, increasing, though, the EE.

\subsection{Cost per Ton Carbon Saved}

The lifecycle analysis over a thirty years lifetime (chosen as a likely lifespan of the refurbishment measures) combines the pre refurbishment operational data with those for post intervention operation and embodied ones as well. The CTS arises as a quotient of the LC divided by the LCS. The savings arising from the EnerPHit refurbishment are constantly higher, although, due to the high amount of EE associated with it, the LCS is higher in the case of the current refurbishment.

The resulting CTS can be evaluated through a comparison to the Social Cost of Carbon for 2012 ( $£ 19 / \mathrm{tCO}_{2}$ with 2000 prices, inflated to 2012 prices) of $£ 27.17 / \mathrm{tCO}_{2}$ (Department of Environment Food and Rural Affairs, 2007b), which represents the global cost of the damage a ton of carbon causes over its lifetime in the atmosphere and the price that society should be paying to prevent or mitigate the damage caused.

In both cases the CTS is way above the SCC, with the EnerPHit retrofit being 1.3 times higher than the current refurbishment, indicating that the extra initial cost and EE involved are not overset by the higher savings during the operational phase of the building. In addition, the carbon savings for the EnerPHit are 
quite delayed compared to the current retrofit, where savings begin just before the second year, resulting always (values checked for 250 years) in higher CTS (Figure 10). After the 13th year the carbon savings from EnerPHit outreach the current refurbishment.

\section{Figure 10 CTS and LCS Comparison}

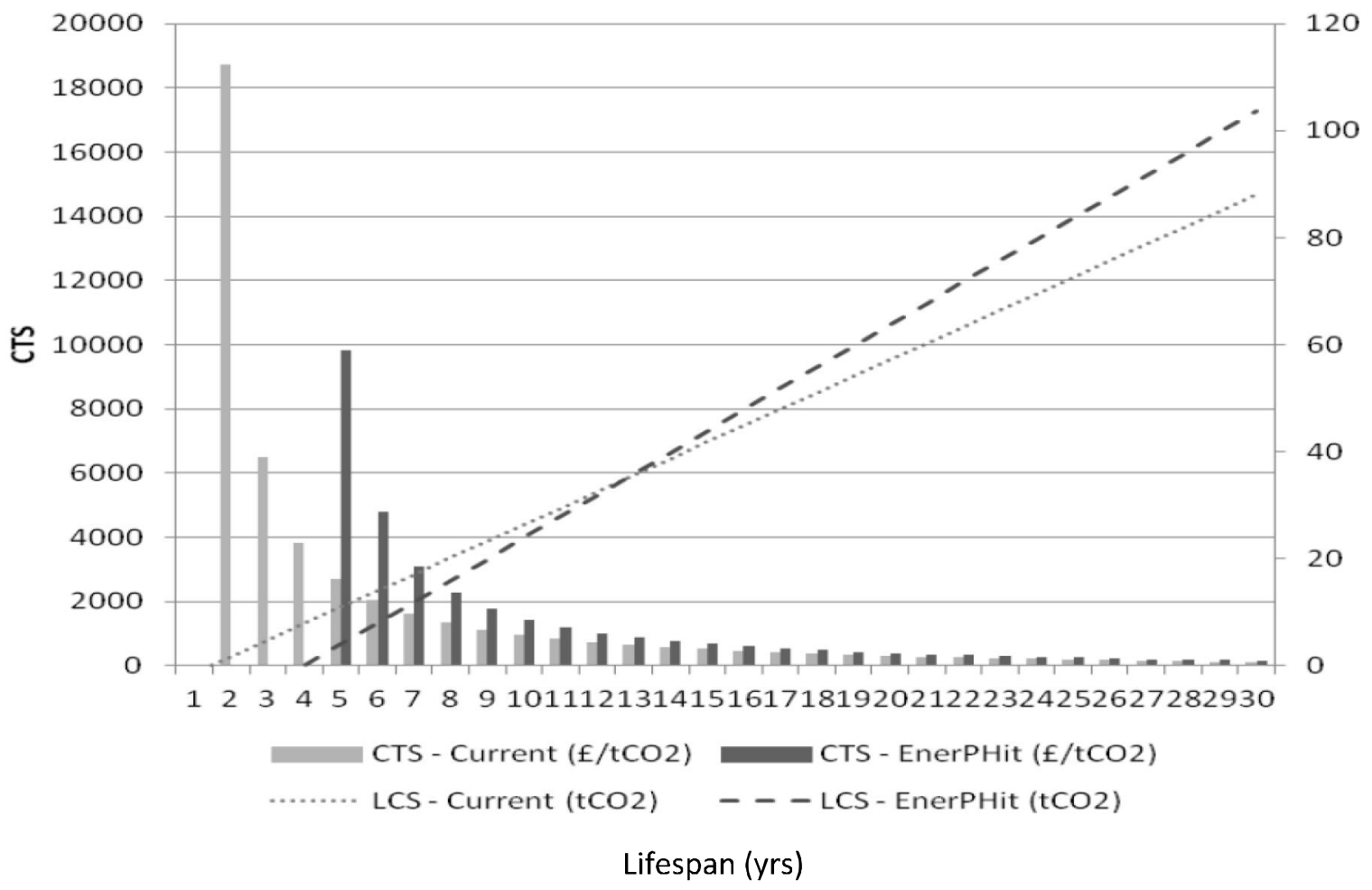

\subsection{Financial Evaluation}

Simple payback compares the capital investment for a project with the annual benefit, which is assumed to be the same every year, giving the payback period. This method ignores time preference, discounting and the benefits after the payback period and thus should be only used for initial calculations (Ellingham and Fawcett, 2006).

In both cases the capital costs are not expected to be repaid after the end of life of the project (30 years), rendering both interventions not cost - effective. With regards to Carbon and Energy, the current refurbishment shows, as expected, shorter payback periods (Table 7).

Table 7 Simple payback

\begin{tabular}{|l|l|r|r|}
\hline & & Current Refurbishment & EnerPHit Refurbishment \\
\hline Simple Payback & years & 43.18 & 47.38 \\
\hline Carbon Payback & years & 1.45 & 4.01 \\
\hline Energy Payback & years & 5.21 & 7.75 \\
\hline
\end{tabular}

The cash flow of a project associated with future expenditures and incomes is greatly influenced by time preference, which derives from the natural desire to enjoy benefits as soon as possible and to defer payments as long as possible (Ellingham and Fawcett, 2006). The most critical assumption of LCC is the 
discount rate, as a high one gives great emphasis on the early years of the project, favouring short term approaches, while low $r$ favours higher capital investment and a long - term approach. As this project involves low risk, a discount factor of $3.5 \%$ was assumed, reflecting the time preference of the UK society (Ellingham and Fawcett, 2006). The results of net present value (NPV) for the two alternatives showed that none of the two would give payback in a reasonable amount of time, if discounting is taken into account and steady gas prices are assumed, with EnerPHit having a higher deficit.

\subsection{CTS of individual measures}

The CTS analysis over a 30 years lifetime for the individual measures applied on the thermal envelope reveals that only the EnerPHit roof insulation would be repaid and begins to give monetary benefit from the $21^{\text {st }}$ year, due to the significant operational energy savings and low EC (Figure 11). The least efficient measures are concluded to be the current party wall insulation and the EnerPHit ground floor insulation, as they fail to save any carbon within this period. All in all, only windows and ground floor insulation perform better for the current retrofit strategy in terms of CTS. As far as payback times are concerned, the party wall insulation and window replacement are not expected to be ever repaid in both cases, while all measures' times are extremely high, excluding roof insulation, leading yet again to the conclusion that only with rising gas prices these interventions are viable (Figure 12).

Figure 11 CTS Comparison of Individual Measures

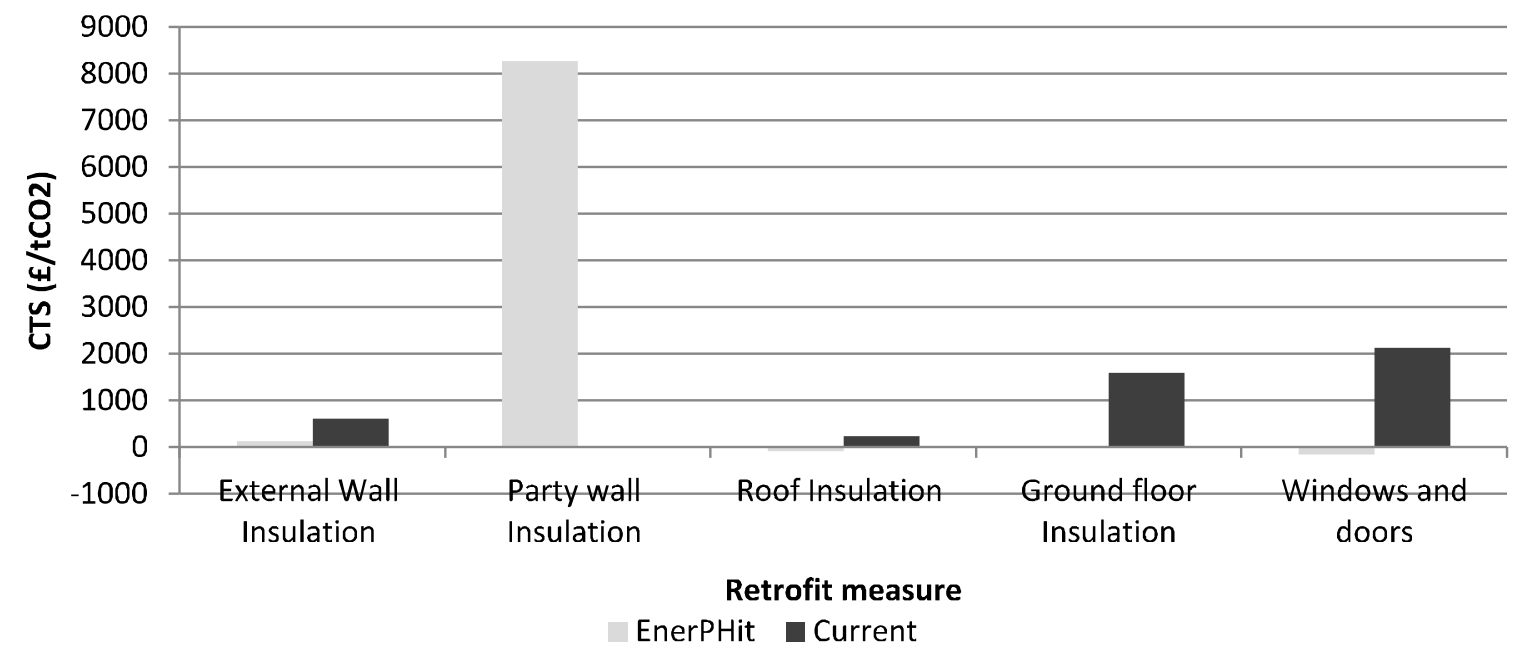


Figure 12 Simple Payback Comparisons of Individual Measures

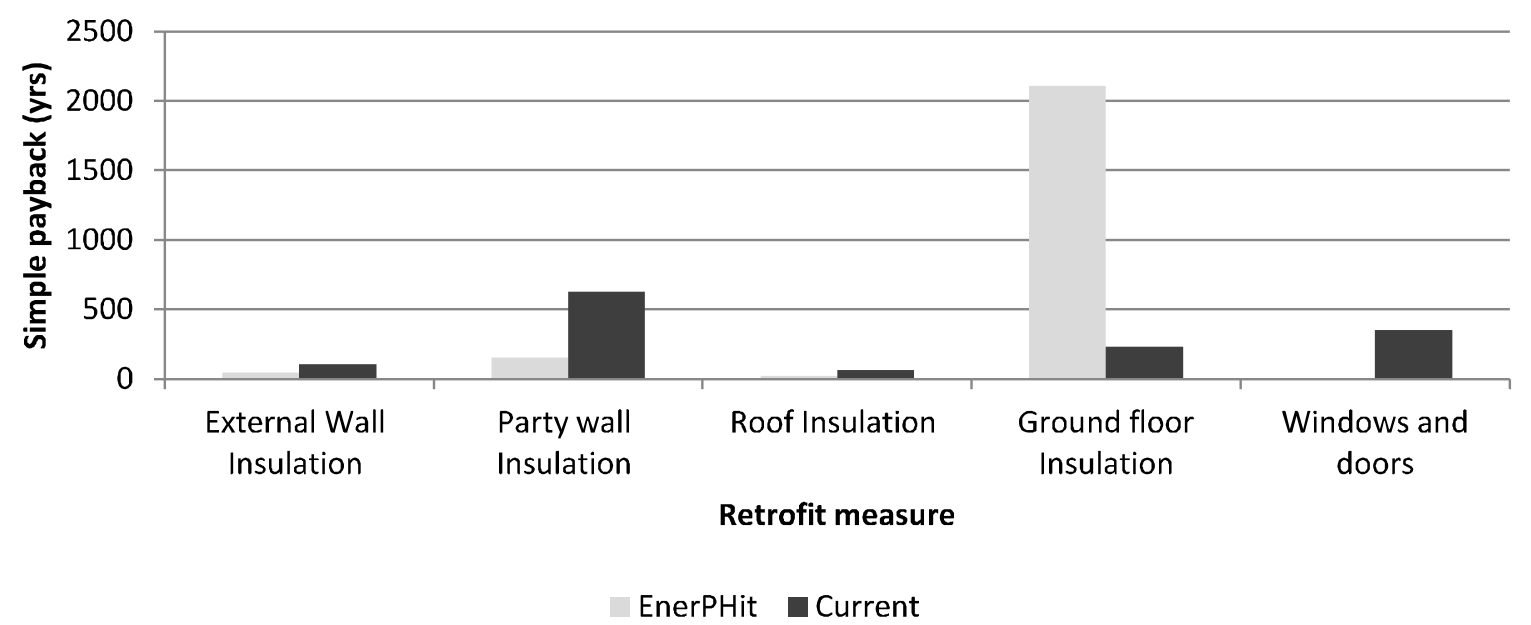

\section{SENSITIVITY ANALYSIS}

In the model developed in this study in order to assess the LCC of the two retrofit cases many assumptions were made and the sensitivity analysis addressed the most important ones.

\subsection{Gas price volatility}

The previous analysis considered steady fuel prices, which is highly unlikely to happen in real life. Fuel price volatility can be measured from historic data and can be used to predict the range of possible future outcomes. A quite widespread tool to do that is the binomial tree. Energy prices show in general upward trends, thus a falling fuel price trend is highly unlikely in NPV costing. The results of the binomial tree for rising and steady fuel prices are summarized in Table 8. With falling gas prices the initial investment is not repaid, so they were not included in the table.

Table 8 Payback time comparison

\begin{tabular}{|c|c|c|c|c|c|}
\hline & & \multicolumn{2}{|c|}{ Current Refurbishment } & \multicolumn{2}{c|}{ EnerPHit Refurbishment } \\
\hline & & Steady fuel price & Rising fuel price & Steady fuel price & Rising fuel price \\
\hline Simple Payback & years & 43.18 & 19 & 47.38 & 22 \\
\hline Discounted Payback & years & - & 24 & - & 25 \\
\hline 30 Year NPV & $\mathrm{E}$ & -20790.33 & 13754.19 & -28465.6 & 13145.84 \\
\hline 30 Year CTS Discounted & f/tCO2 & -614.27 & -698.7 & 254.66 & -614.49 \\
\hline
\end{tabular}

It becomes apparent from Table 8 that only with rising fuel prices the initial investments would be repaid before the project's end of life, with EnerPHit demanding in all cases longer payback periods. Its NPV is exceeding the NPV of the current refurbishment after the 33rd year. As far as CTS is concerned, when discounting and rising fuel prices are applied to the calculations, both cases show negative CTS values, indicating profitable investments. Yet again, the current refurbishment shows a higher benefit, which stays above the EnerPHit one for 50 years (Figure 13). On the other hand, when steady prices and discounting are assumed, only the current refurbishment shows negative CTS in 50 years (Figure 14). 
Figure 13 NPV with rising fuel prices

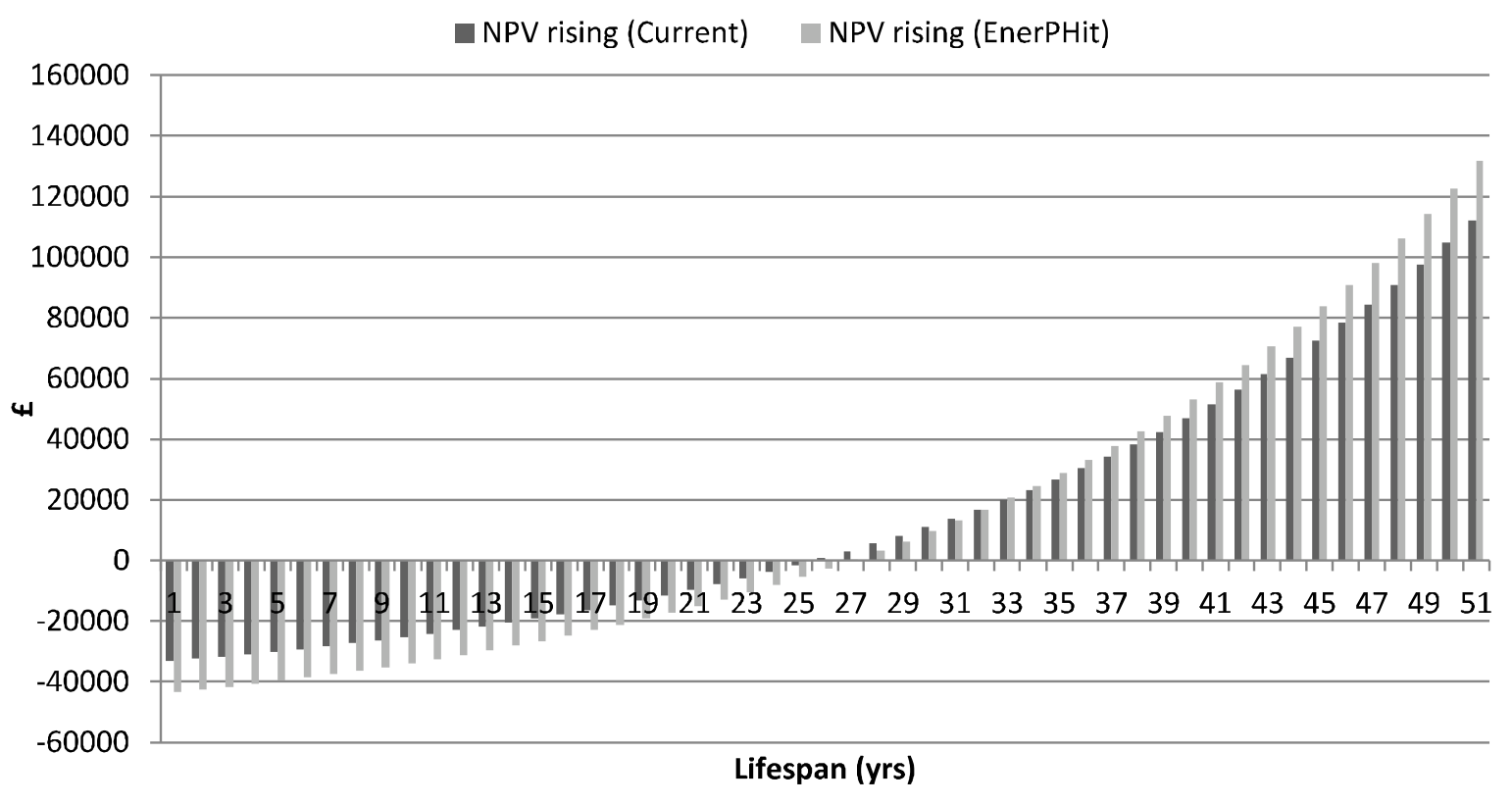

Figure 14 CTS Comparison - Rising fuel prices and discounting

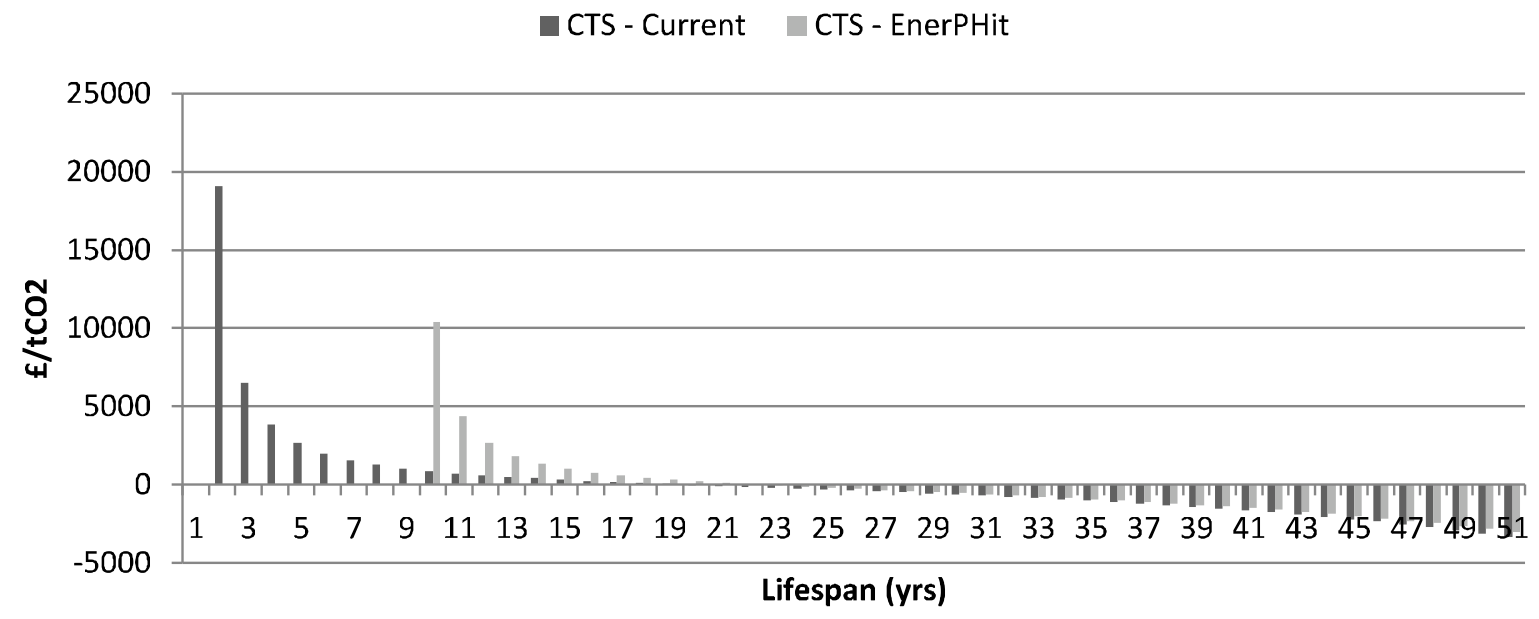

\subsection{Impact of climate change}

In order to test the validity of the results in case of higher temperatures in the future, a new model was developed using London Design Summer Year weather file. As expected, the total energy consumption was reduced in all cases, with heating loads falling and electricity loads increasing due to additional cooling needed. The overall energy savings are minimized in both cases, especially in the current refurbishment and, consequently, CTS and payback times increase. The current retrofit's CTS increased by $50 \%$ and the EnerPHit's by $47 \%$, while carbon and energy payback times all rose in the range of $20 \%$, rendering both interventions less sustainable. Therefore, it is evident that climate change will influence the benefits of retrofit measures as heating loads and, thus, operational energy savings will decrease, a conclusion applicable in the case of retrofit in warmer climates as well. 


\subsection{Lifetime effect on CTS and NPV}

\subsubsection{No replacement}

One of the most substantial assumptions taken during the calculations was the project's lifetime of 30 years. The CTS is sensitive to the lifetime cost savings and the lifetime carbon savings and therefore the assumed lifetime. In all cases, carbon payback must be achieved before the CTS can be calculated. In this section the effect of varying lifespans will be addressed, assuming that no additional cost, EE and EC is needed.

As expected, the CTS for a lifespan smaller than the assumed one leads to a rocketing of the CTS for both retrofit cases, as the operational energy savings are not enough to offset the initial investments. From Figure 15 it becomes clear that for up to 24 years of lifetime the EnerPHit's CTS is lower than the current one, while from the point they equalize until 90 years lifetime it never exceeds the current one. Interestingly, the current refurbishment starts to generate profit from the 43th year and the EnerPHit from the 47 th reaching $f-71.76 / \mathrm{tCO}_{2}$ and $f-51.9 / \mathrm{tCO}_{2}$ by the 60 th year respectively.

\section{Figure 15 Effect of lifespan on CTS}

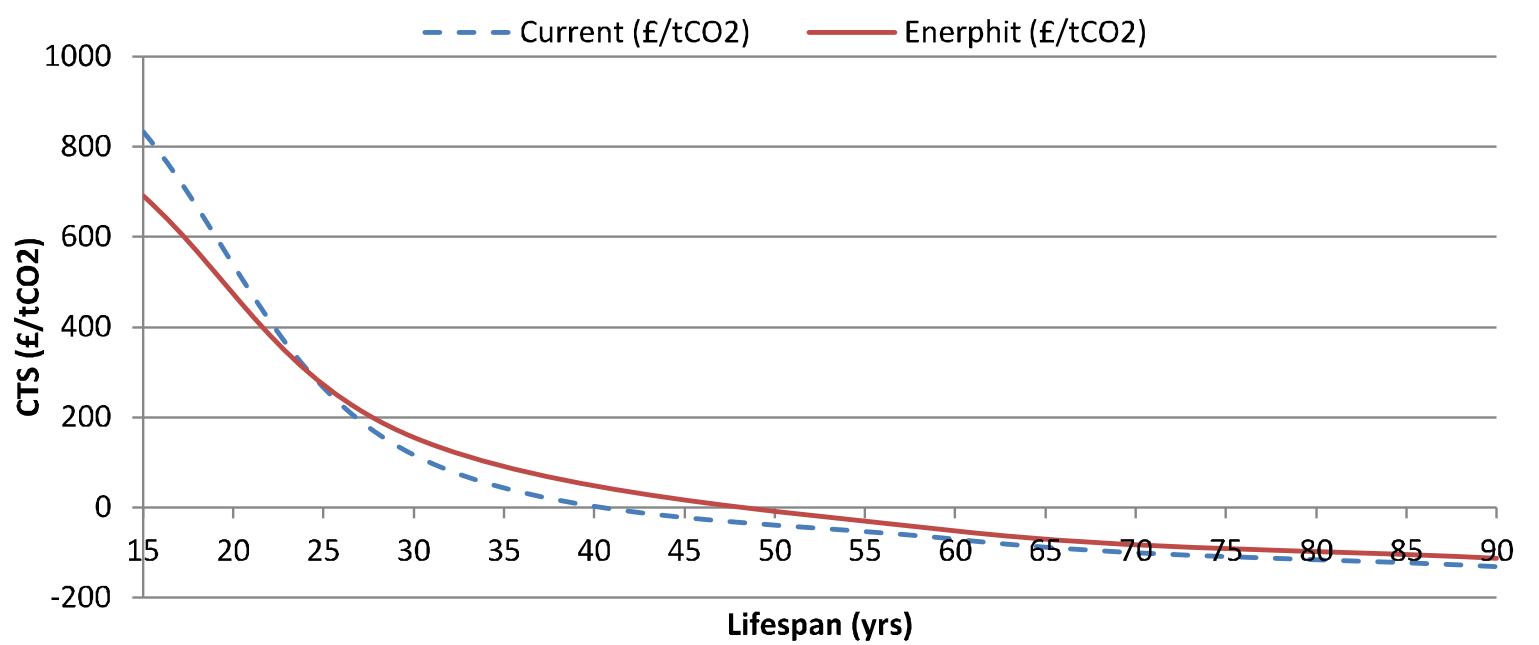

Likewise, the NPV shows different results over different lifetimes. The EnerPHit option becomes more viable than the current one after the 29th year with the difference increasing logarithmically within time, generating very high benefits compared to the initial investment (Figure 16). With steady fuel prices none of the two options is repaid within 90 years.

Figure 16 NPV with rising fuel prices over 90 years 


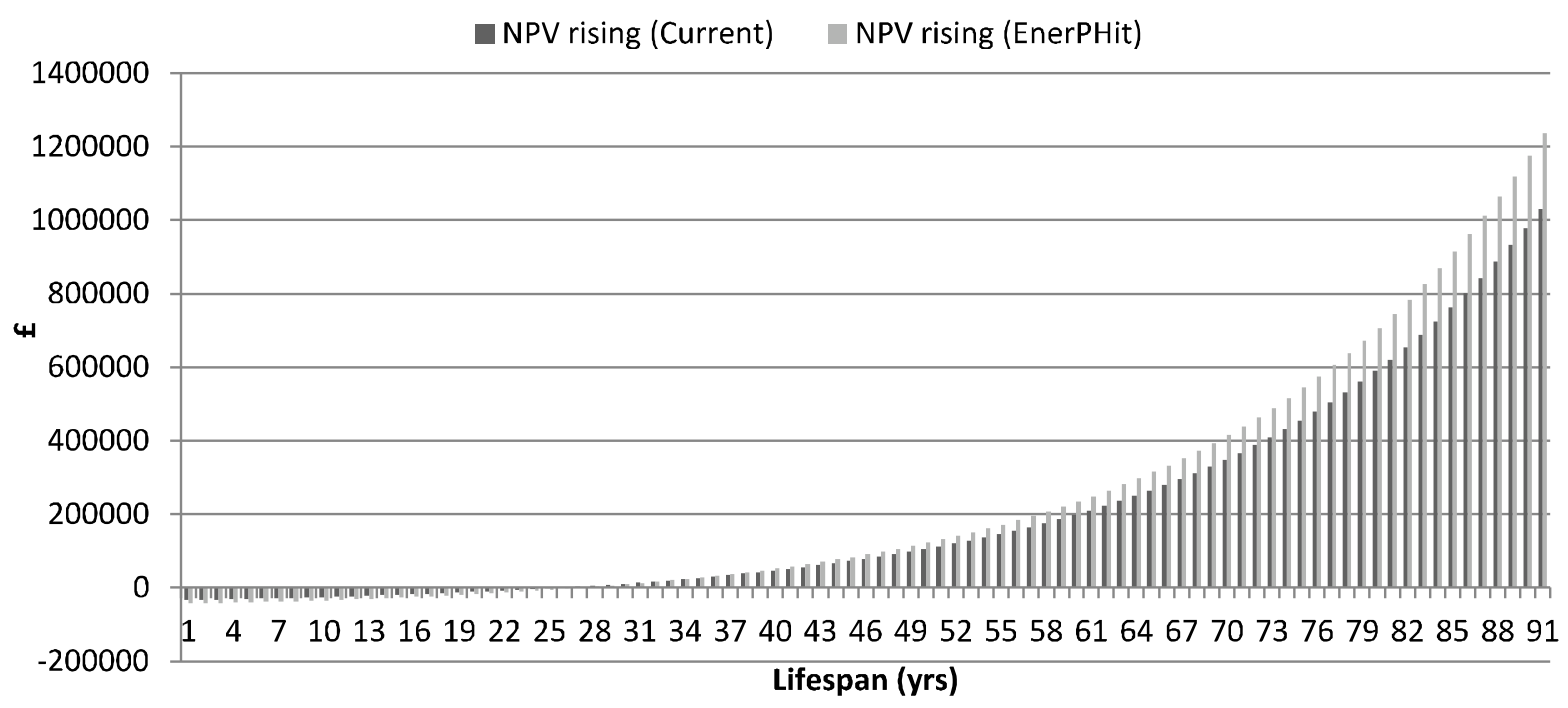

\subsubsection{Replacement}

In the previous section the effect of various lifespans on the CTS of the two retrofits was addressed, assuming that no additional replacements are needed, which could be considered utopian for a 90 years lifespan. Based on Jakob (2006) five replacement cycles were incorporated in the CTS analysis. When these replacements are included, no benefit arises within 90 years. Quite interestingly, the carbon saved in EnerPHit manages to outreach the current after the 13th year, even though it is more decreased by replacement cycles (Figure 17). However, the EnerPHit CTS remains constantly above the current one, leading yet again to the conclusion that it is less sustainable.

Figure 17 CTS and LCS including replacements over 90 years

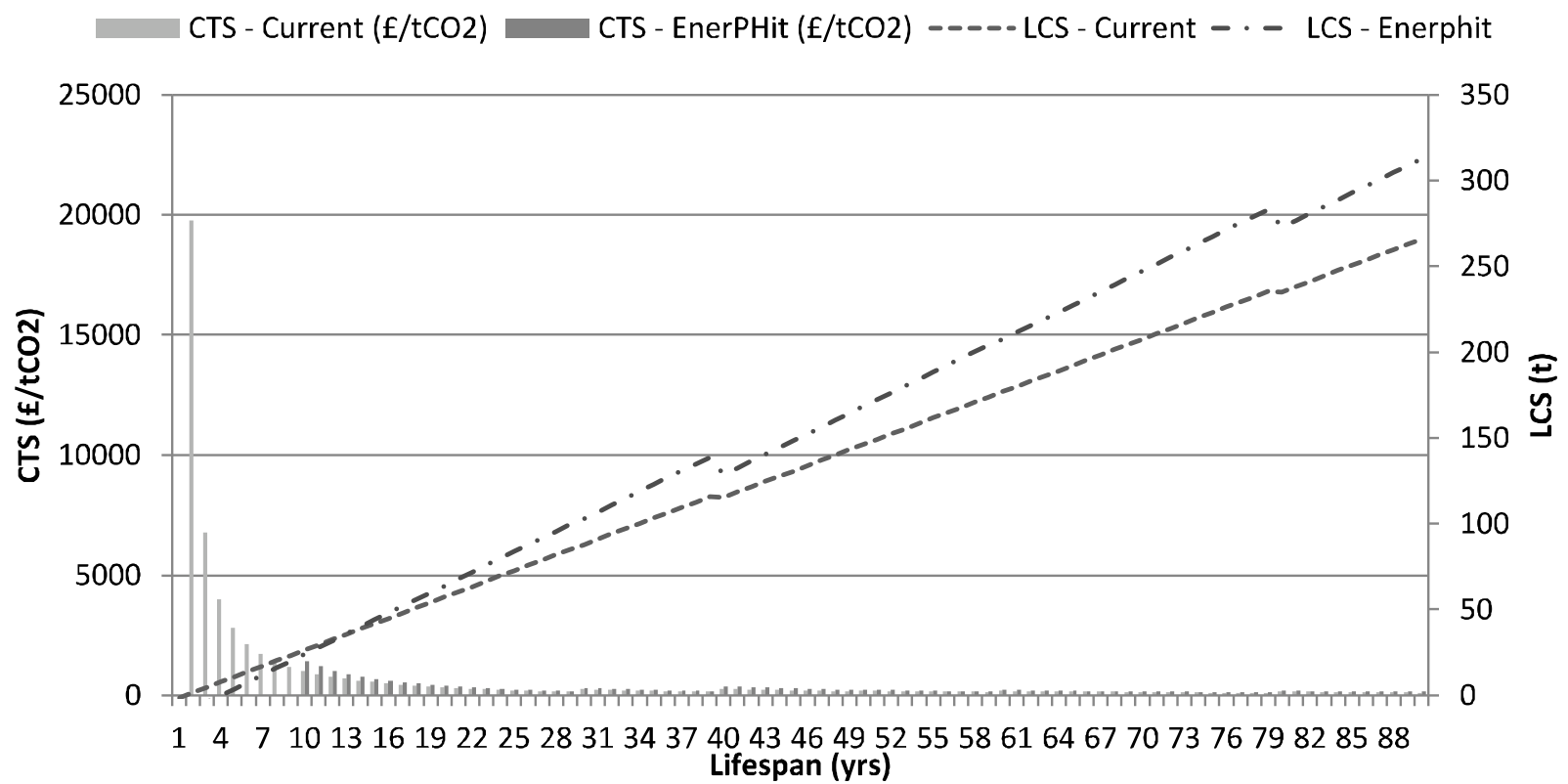

\subsubsection{Discount rate}


As described above, the discount rate is a quantification of uncertainty associated with benefits arising from investments, with high discount rates favouring short-term approaches and vice versa with low. It reflects three factors: inflation, time preference and risk. For the purpose of this study a conservative $r=3.5 \%$ was assumed, based on UK society overall time preference (Ellingham and Fawcett, 2006).

This assumption was tested against the effect it has on the two strategy's NPV with rising gas prices, resulting in favour of the EnerPHit for $r<3.25 \%$ confirming the sensitivity of the results to this input and the fact that low discount rates are advantageous for long term approaches and higher initial investments (Figure 18).

\section{Figure 18 Effect of $r$ to NPV}

405

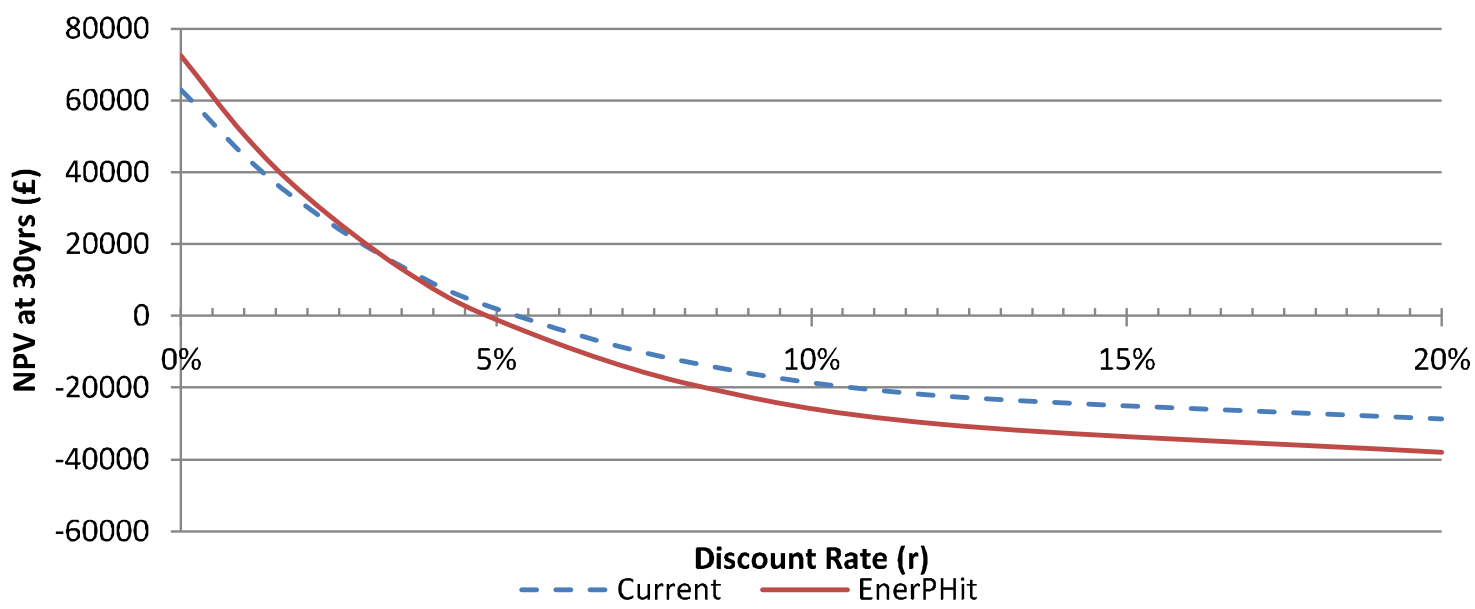

\subsubsection{Overheating Occurrence}

In the previous sections the study was focused on energy consumption; however, one of the main aspects of retrofit is the improvement of the house's thermal conditions, as these have implications on occupants' health and comfort. In addition, one of the EnerPHit refurbishment's criteria is the restraint of the overheating percentages $\left(t>25^{\circ} \mathrm{C}\right)$ below $10 \%$. The pre - retrofit, the current and the EnerPHit cases were tested against this constraint over a 24 hour basis, except for the guest room which is tested only when occupied. Both refurbished cases show significantly low overheating percentages, quite below the strict limit of $10 \%$ over $25^{\circ} \mathrm{C}$.

In order to identify the different responses of the house during hot periods, the hottest day of the weather file was chosen and the temperatures in the main living space were modelled (Figure 19). The EnerPHit house performed better, having a $3.4^{\circ} \mathrm{C}$ difference of maximum temperature with the outside, followed by the current refurbishment, which responded a little worse. On the other hand, by using the DSY the frequency of overheating appears to be higher for the EnerPHit case (4\%), when no additional cooling is implemented. 


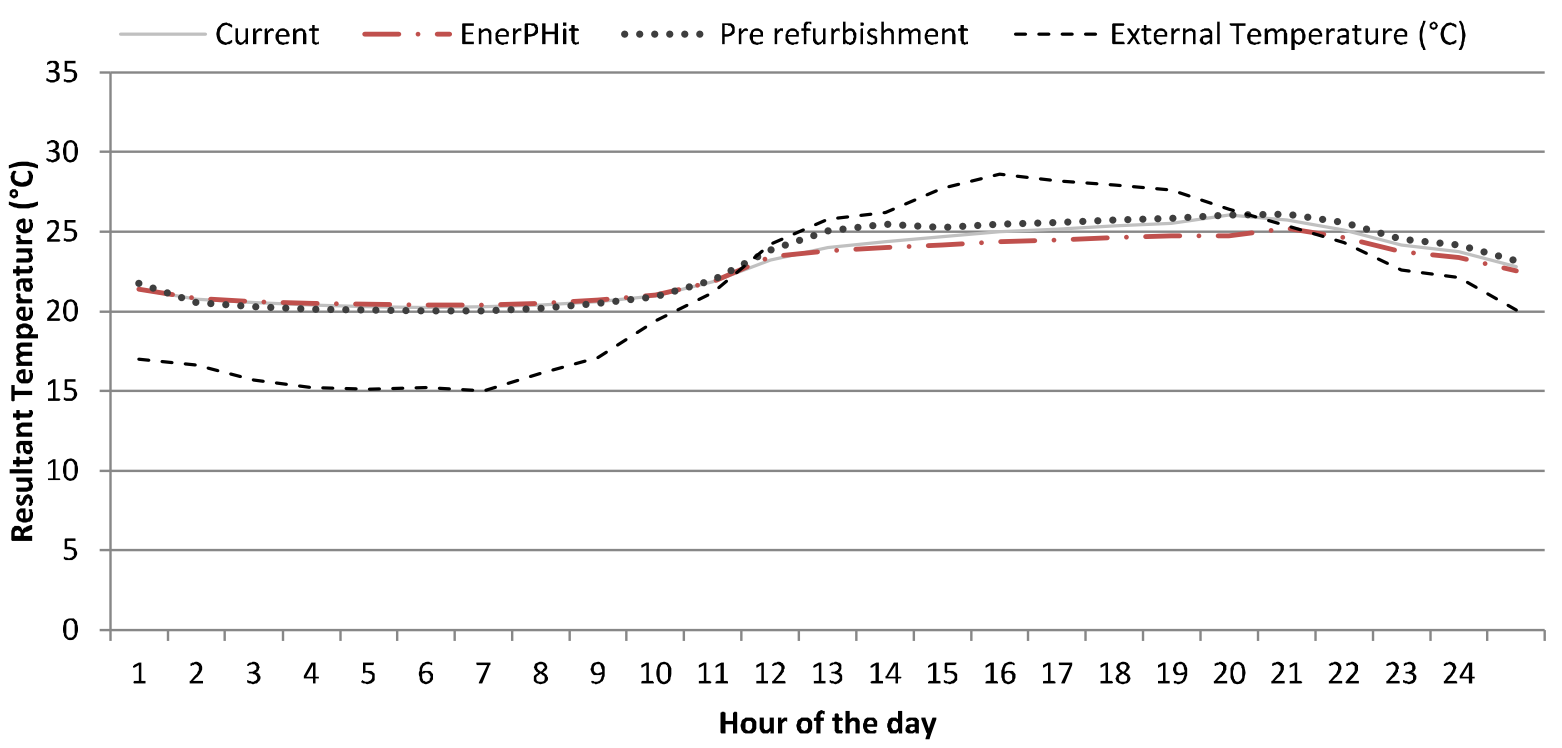

\section{DISCUSSION}

Whole Life Cycle assessment is a useful tool to evaluate retrofit measures, capable of giving important results (Gustafsson and Karlsson, 1988). However, the enormous amount of data inputs and calculations in order to find the optimal retrofit strategy may lead to deviations that will influence the results and is thus important to be aware of the study's limitations and boundaries.

As this study dealt with a comparison between an applied and a theoretical retrofit strategy, there is an amount of uncertainty concerning the applicability of the latter. Quite often the proposal of thicker insulation levels is not feasible, as space or level heights' issues arise. Another important parameter is detailing. The possibility of thermal bridges cannot be modelled with the software used, leading to underestimation of heating loads and costs, as well. Furthermore, some of the proposed retrofit measures such as the insulation of the end terrace wall externally and the sash - like windows with triple glazing may undergo obstructions due to conservation restrictions.

With regards to thermal analysis, the results of the modelling have a marginal uncertainty. The same applies to the air-tightness levels of the initial house and the EnerPHit one, as they were based on assumptions. One of the factors influencing actual and modelled energy consumption is occupant behaviour and even though the occupancy schedule and the thermostats were formed in cooperation with the house owner, there are still some imponderable factors, such as the appliances' use or the occupancy of the guest room, which affect the internal gains.

The costing of the retrofit strategies was based on Langdon (2013). Cost data were available for the current refurbishment; however those were used as a guide only, as they were based on 2006 prices and could not be comparable with 2013 prices for the EnerPHit. Inflating the costs to 2013 prices was not preferred as an option, since the cost of some products (such as triple glazed windows) falls within time as their application becomes more widespread and more technologically advanced products emerge. Some uncertainty factors concerning costing were the additional costs for the transport of products, detailing and air tightness works. For the latter limited data are available on the costs associated with undertaking remedial work in dwellings and due to this it was omitted from CTS analysis for individual measures.

The boundary conditions of this input could be another limitation, as considering only the EE and ECO2 from Cradle - to - Gate and omitting Gate - to - Site values, could influence the results. For those data specific manufacturers' data and their distance from the site are needed, which were not available. 
However, Hammond and Jones (2008) declare that the difference between Cradle - to - Gate and Cradle - to - Site especially for materials with high embodied energy is negligible. Furthermore, the difference in the distances from factory to site between the two cases is considered unimportant for the results.

Besides all the above, there were also some other points of uncertainty, which were addressed by the sensitivity analysis. One of them is energy prices and how will they form in the future, an issue looked into with the use of the binomial tree. The others are the lifetime of the project and its effect on the return of investment and the assumed discount rate and its effect on NPV. Those factors are considered to be thoroughly investigated and that their effects on the results have been evaluated.

\section{CONCLUSIONS}

The aim of this work was to evaluate the most sustainable way to refurbish the thermal envelope of an end - terraced house in London, by comparing cost, EE and ECO2 between the applied retrofit and EnerPHit standard. At first glance one would assume that since EnerPHit is based on stricter U-Values and therefore higher insulation levels, it would be the optimum alternative by achieving higher operational energy savings, which is translated in cost savings. However, this study proved this hypothesis wrong, as the EnerPHit's price to be paid in order to achieve those higher energy savings in terms of IC, EE and ECO2 renders it a less appealing retrofit model than the applied one.

This study used the cost payback time as a means to compare the two models, with quite interesting results. First and foremost, it was concluded that with steady (and falling) fuel prices none of the two is ever repaid when discounting is taken into account. In addition, if the imminent climate change is taken into account, both retrofit models appear to be unworthy, with extremely long payback times, as energy savings from heating decrease with higher external temperatures. However, with rising fuel prices, which are highly probable according to trends, the two models are repaid within 19 years for the current one and 22 for EnerPHit, with the financial benefits coming from the EnerPHit exceeding the current one after the $33 \mathrm{rd}$ year, ending in $20 \%$ more NPV in the 90th year (without taking replacements into account). This inference led to another important one: the definition of the lifetime's length is very important in WLC, as significant benefits may arise after the end of the assumed lifespan, leading to incorrect conclusions. Thus, when a building is structurally intact and expected to exist for a long time, it is worth to invest in an extensive retrofit.

One should not overlook that retrofitting has to play an important role on the reduction of $\mathrm{CO} 2$ emissions, as the existing UK housing stock is among the least energy efficient in Europe and is therefore a great contributor to climate change. In addition, energy refurbishment increases the property value and thus rent premiums, improves health and comfort conditions in the house and also acts against fuel poverty. In 20114.5 million UK households were spending more than $10 \%$ of their income in order to maintain adequate warmth (Department of Energy and Climate Change, 2013), making the great importance of building fabric to occupant's health apparent, especially to those with lower income. Moreover, retrofit is one of the tools for a gradual release from fossil fuel energy consumption, as the minimization of operational energy makes it feasible to supply a big part of this energy through renewables. Finally, it contributes positively to the creation of work places, especially in densely built cities with low construction rates, a financial benefit that should not be disregarded.

All in all it's always a matter of how much do we really spend in order to save.

\section{ACKNOWLEDGEMENTS}

I would like to express my gratitude to the following people for their help on this research and completion of the dissertation:

Ben Croxford, dissertation supervisor, for always being eager to offer his time and advice throughout the dissertation. 
Sarah Harrison, the house owner, for giving access to her house, information about the refurbishment and her metering records.

My family and friends for their invaluable support all along.

\section{REFERENCES}

505 Boardman, B., Sarah Darby, Gavin Killip, M. H., Christian N. Jardine, Palmer, J. \& Sinden, G. 2005. 40\% House [Online]. University of Oxford. Available: www.eci.ox.ac.uk [Accessed 11/06/2013].

Camden Council 2009. Dartmouth Park Conservation Area Appraisal and Management Statement. In: COUNCIL, C. (ed.).

DECC 2012. Domestic energy consumption in the UK since 1970. In: CHANGE, D. O. E. A. C. (ed.).

Department Of Energy And Climate Change 2013. Annual Report on Fuel Poverty Statistics 2013. London.

Department Of Environment Food And Rural Affairs. 2007a. Guidelines to Defra's GHG conversion factors for company reporting.

Department Of Environment Food And Rural Affairs 2007b. The Social Cost of Carbon and the

515 Shadow Price of Carbon: What They Are, and How To Use Them in Economic Appraisal in the UK. In: DEFRA (ed.). London.

Dodoo, A., Gustavsson, L. \& Sathre, R. 2010. Life cycle primary energy implication of retrofitting a wood-framed apartment building to passive house standard. Resources, Conservation and Recycling, 54, 1152-1160.

520 Dowson, M. 2012. 18: Passivhaus Refurbishment [Online]. Available:

http://www.cibse.org/content/microsites/epg/cb18.pdf.

Ellingham, I. \& Fawcett, W. 2006. New generation whole-life costing : property and construction decision-making under uncertainty.

European Commission. 2009. Low Energy Buildings In Europe: Current State Of Play, Definitions And

Best Practice. Available: http://ec.europa.eu/energy/efficiency/doc/buildings/info_note.pdf.

European Commission 2013. EU greenhouse gas emissions and targets.

Feist, W. 1997. Life-Cycle Energy Analysis: Comparison Of Low-Energy House, Passive House, Self-

Sufficient House.

Feist, W. 2011. EnerPHit Certification as "Quality Approved Energy Retrofit with Passive House

Components". In: INTITUTE, P. H. (ed.). Darmstadt.

Fuller, S. 2010. Life-Cycle Cost Analysis (LCCA)

[Online].Available:http://www.wbdg.org/resources/lcca.php [Accessed 09/06/2013].

Gignac, F. G. \& Jensen, M. V. 2007. Environmental Impacts Of Passive Houses.

Green Deal Initiative. Green Deal for Home Owners [Online]. Available:

http://www.greendealinitiative.co.uk/about-the-green-deal/the-green-deal-for-homes/ [Accessed 20/08/2013].

Gustafsson, S. \& Karlsson, B. G. 1988. Why is life cycle costing importnat when retrofitting buildings Hall, K. 2005. The green building bible : all you need to know about ecobuilding / publishing editor:

Keith Hall, Green Building Press.

Hammond, G. \& Jones, C. 2008. Inventory Of Carbon \& Energy (ICE). Department of Mechanical

Engineering University of Bath, UK.

Harrison, S. Available: http://www.eco-refurbishment.co.uk/ [Accessed 05/06/2013].

Hermelink, A. 2009. The life cycle race - silver and bronze go to ... passive house and low energy house. ECEEE 2009 Summer Study • Act! Innovate! Deliver! Reducing Energy Demand Sustainably 545 [Online]. 
Hernandez, P. \& Kenny, P. 2010. From net energy to zero energy buildings: Defining life cycle zero energy buildings [Online]. Elsevier.

HMSO 2008. Climate Change Act 2008. London.

HMSO 2010. Conservation Of Fuel In Existing Buildings The Building Regulations.

HMSO 2011. The Carbon Plan: Delivering our Low Carbon Future. In: CHANGE, D. O. E. C. (ed.).

London.

HMSO 2013a. Code for Sustainable Homes and Energy Performance of Buildings. In: GOVERNMENT, D. F. C. A. L. (ed.).

HMSO 2013b. English Housing Survey Headline Report 2011-12. In: GOVERNMENT, D. F. C. A. L. (ed.).

555 London: Crown.

ISO. 2003. Task Group 4: Life Cycle Costs in Construction. In LCC as a contribution to sustainable construction-Final [Online]. London. Available:

http://www.ceetb.eu/docs/Reports/LCC\%2OFINAL\%20REPORT-2.pdf [Accessed 09/06/2013].

Jakob, M. 2006. Marginal costs and co-benefits of energy efficiency investments. Energy Policy, 34,

$560 \quad 172-187$.

Johnston, D., Miles-Shenton, D., Bell, M. \& Wingfield, J. 2011. Airtightness of buildings - towards higher performance

Final Report - Domestic Sector Airtightness London: Centre for the Built Environment, Leeds Metropolitan University.

565 Kah, O. \& Feist, W. 2005. Wirtschaftlichkeit von Wärmedämm-Maßnahmen im Gebäudebestand Available:http://www.passipedia.org/passipedia_en/_media/picopen/wirtschaftlichkeit_waermedaem mung.pdf [Accessed 12/06/2013].

Kbob. 2009. Ökobilanzdaten im Baubereich [Online]. Available:

http://www.ecobau.ch/index.cfm?Nav=20 [Accessed 10/07/2013].

Langdon, D. 2013. Spon's architects' and builders' price book 2013 London.

Lowe, R. 2007. Technical options and strategies for decarbonizingUK housing. Building Research \& Information [Online]. Available: http://www.tandf.co.uk/journals [Accessed 11/06/2011].

Marc, J. 2001. Energy and choice of life [Online]. Available: www.manicore.com [Accessed 06/06/2013].

Marc, J. 2003a. What is our present energy consumption like ? [Online]. Available:

www.manicore.com [Accessed 06/06/2013].

Marc, J. 2003b. What is the greenhouse effect? [Online]. Available: www.manicore.com [Accessed 06/06/2013].

Mcmullan, R. 2007. Environmental science in building / Randall McMullan, Basingstoke : Palgrave Macmillan

Metoffice. 2009. Science: Driving our response to climate change [Online]. Available:

http://www.metoffice.gov.uk/media/pdf/r/6/informing-mitigation.pdf [Accessed 06/06/2013].

Mohammadpourkarbasi, H. 2013. The Eco-Refurbishment of a 19th Century Terraced House: Energy and Cost Performance for Current and Future UK Climates. Buildings, 3, 220.

National Statistics. 2013. Quarterly Energy Prices [Online]. Department of Energy and Climate Change.

Nicholls, R. 2005. The green building bible : all you need to know about ecobuilding / publishing editor: Keith Hall,Green Building Press.

Passipedia. Economic feasibility of Passive House retrofits [Online]. Available:

590 http://www.passipedia.org/passipedia_en/basics/affordability/investing_in_energy_efficiency/economi c_feasibility_of_passive_house_retrofits [Accessed 12/06/2013].

Pelsmakers, S. 2012. The environmental design pocketbook / Sofie Pelsmakers. 
Power, A. 2008. Does demolition or refurbishment of old and inefficient homes help to increase our environmental, social and economic viability? Energy Policy [Online], 36.

Royal Commission On Environmental Pollution. 2007. The Urban Environment: Summary of the Royal Commission on Environmental Pollution's Report. Available: http://www.rcep.org.uk [Accessed

11/06/2013].

Saltelli A., Ratto M., Andrest., Campolongo F., Cariboni J., D., G., Saisana, M. \& S., T. 2008. Global Sensitivity Analysis [Online]. ohn Wiley \& Sons.

Schnieders, J. \& Hermelink, A. 2006. CEPHEUS results: measurements and occupants' satisfaction provide evidence for Passive Houses being an option for sustainable building. Energy Policy, 34, 151-171.

Stern, N. 2007. The economics of climate change : the Stern review, Cambridge University Press.

Super Homes. Available: http://www.superhomes.org.uk/superhomes/chester-road-northcamdenlondon/[Accessed 05/06/2013].

605 Taylor, J. 2008. Available: http://www.buildingconservation.com /articles/consent/consent.htm [Accessed 05/06/2013 2013].

Thorpe, D. 2010. Sustainable Home Refurbishment : The Earthscan Expert Guide to Retrofitting Homes for Efficiency.

United Nations. 2004. World Population To 2300 [Online]. New York. Available:

610 http://www.un.org/esa/population/publications/longrange2/WorldPop2300final.pdf [Accessed 06/06/2013].

United Nations. 2013. Kyoto Protocol [Online]. Available: http://unfccc.int/kyoto protocol/ items/2830.php [Accessed 07/06/2013].

University Of Reading 1985. Life cycle costs for architects : a draft design manual, Whiteknights,

615 Reading: College of Estate Management

\section{TABLE OF TABLES}

Table 1 Refurbishment of building envelope

Table 2 Summary of the three iterations' $U$ values $(\mathrm{W} / \mathrm{m} 2 \mathrm{~K})$

Table 3 Efficiency and $\mathrm{CO} 2$ factors (Department of Environment Food and Rural Affairs, 2007a,

National Statistics, 2013)

Table 4 Indicators and Units

Table 5 Retrofit measures' effect on heating loads

Table 6 Comparison of insulation ECO2

625 Table 7 Simple payback

Table 8 Payback time comparison

\section{TABLE OF FIGURES}

Figure 1 Front Elevation

630 Figure 2 Ground Floor Plan (not in scale)

Figure 3 Passive measures (thermal envelope only)

Figure 4 Energy Use Breakdown ( $\mathrm{KWh} / \mathrm{m} 2 \mathrm{a})$

Figure 5 Heating Loads $(\mathrm{kWh} / \mathrm{m} 2)$ and retrofit measures

Figure 6 Total Costs $(f / \mathrm{m} 2)$

Figure 7 Embodied Energy (MJ/m2)

Figure 8 Embodied $\mathrm{CO} 2(\mathrm{~kg} / \mathrm{m} 2)$

Figure 9 Representative construction details

Figure 10 CTS and LCS Comparison

Figure 11 CTS Comparison of Individual Measures 
640 Figure 12 Simple Payback Comparison of Individual Measures Figure 13 NPV with rising fuel prices

Figure 14 CTS Comparison - Rising fuel prices and discounting Figure 15 Effect of lifespan on CTS

Figure 16 NPV with rising fuel prices over 90 years

645 Figure 17 CTS and LCS including replacements over 90 years Figure 18 Effect of $r$ to NPV

Figure 19 Living room resultant temperature 


\section{HIGHLIGHTS}

- Two retrofitting strategies were compared based on cost-effectiveness, embodied and operational energy and $\mathrm{CO} 2$.

- The Cost per Ton carbon Saved was higher for the most extensive one.

- The cost-effectiveness of retrofitting depends on gas prices, discount rates, the building's lifespan and the climatic factor. 